\title{
Mantle to surface degassing of alkalic magmas at Erebus volcano, Antarctica
}

Clive Oppenheimer ${ }^{\mathrm{abc}}$

Roberto Moretti ${ }^{\mathrm{de}}$

Philip R. Kyle ${ }^{\underline{\mathrm{f}}}$

Al Eschenbacher ${ }^{\mathrm{f}}$

Jacob B. Lowenstern ${ }^{\mathrm{g}}$

Richard L. Hervig ${ }^{\underline{h}}$

Nelia W. Dunba ${ }^{\mathrm{i}}$

${ }^{a}$ Le Studium, Institute for Advanced Studies, Orléans and Tours, France

${ }^{\mathrm{b}}$ L'Institut des Sciences de la Terre d'Orléans, l'Université d'Orléans, 1a rue de la Férollerie, 45071 Orléans, Cedex 2, France

${ }^{c}$ Department of Geography, University of Cambridge, Downing Place, Cambridge CB2 3EN, UK

${ }^{\mathrm{d}}$ Centro Interdipartimentale di Ricerca in Ingegneria Ambientale (CIRIAM) \&

Dipartimento di Ingegneria Civile, Seconda Università degli Studi di Napoli, Via Roma 29, 80131, Aversa (CE), Italy

e Istituto Nazionale di Geofisica e Vulcanologia, Sezione Osservatorio Vesuviano, Via Diocleziano 328, 80124 Napoli, Italy

${ }^{\mathrm{f}}$ Department of Earth \& Environmental Science, New Mexico Institute of Mining and Technology, Socorro, NM 87801, USA

${ }^{\mathrm{g}}$ Volcano Hazards Team, U.S. Geological Survey, 345 Middlefield Road, Menlo Park, CA 94025, USA

${ }^{\mathrm{h}}$ School of Earth and Space Exploration, Arizona State University, Box 871404, Tempe, AZ 85287-1404, USA

${ }^{\mathrm{i}}$ Bureau of Geology and Mineral Resources, New Mexico Institute of Mining and Technology, Socorro, NM 87801, USA 


\begin{abstract}
Continental intraplate volcanoes, such as Erebus volcano, Antarctica, are associated with extensional tectonics, mantle upwelling and high heat flow. Typically, erupted magmas are alkaline and rich in volatiles (especially $\mathrm{CO}_{2}$ ), inherited from low degrees of partial melting of mantle sources. We examine the degassing of the magmatic system at Erebus volcano using melt inclusion data and high temporal resolution open-path Fourier transform infrared (FTIR) spectroscopic measurements of gas emissions from the active lava lake. Remarkably different gas signatures are associated with passive and explosive gas emissions, representative of volatile contents and redox conditions that reveal contrasting shallow and deep degassing sources. We show that this unexpected degassing signature provides a unique probe for magma differentiation and transfer of $\mathrm{CO}_{2}$-rich oxidised fluids from the mantle to the surface, and evaluate how these processes operate in time and space. Extensive crystallisation driven by $\mathrm{CO}_{2}$ fluxing is responsible for isobaric fractionation of parental basanite magmas close to their source depth. Magma deeper than 4 kbar equilibrates under vapour-buffered conditions. At shallower depths, $\mathrm{CO}_{2}$-rich fluids accumulate and are then released either via convectiondriven, open-system gas loss or as closed-system slugs that ascend and result in Strombolian eruptions in the lava lake. The open-system gases have a reduced state (below the QFM buffer) whereas the closed-system gases preserve their deep oxidised signatures (close to the NNO buffer).
\end{abstract}

\title{
Keywords
}

$\mathrm{CO}_{2}$ fluxing; degassing; Strombolian eruptions; lava lake; melt inclusions; redox

\section{Introduction}

Erebus, the world's southernmost active volcano, offers an exceptional opportunity to examine the complexities that accompany degassing and evolution of magmas from deep to shallow levels. These include generic aspects of magmatic differentiation, redox evolution and eruptive transitions that are widely relevant to understanding other volcanic systems. Its long-lived anorthoclase phonolite lava lake has sustained emission of magmatic gases to the atmosphere for decades (Giggenbach et al., 1973) providing especially favourable circumstances for direct measurement of the magmatic system. Emissions rates of $\mathrm{SO}_{2}$ have been measured by ultraviolet absorption spectroscopy since 1983 (Sweeney et al., 2008) and the relative abundances of many constituents of the plume (including gas and aerosol phases) have been measured using sampling equipment sited on the crater rim (Zreda-Gostynska et al., 1997) and open-path Fourier transform infrared (FTIR) spectroscopy (Oppenheimer and Kyle, 2008).

High emission rates of $\mathrm{CO}_{2}$ from both the crater and a number of fumarolic ice towers scattered around the summit flanks have also been measured ( [Wardell et al., 2004] and [Werner and Brantley, 2003]), revealing the presence of a $\mathrm{CO}_{2}$-rich magma reservoir. The adjacent basaltic volcanic centres of Mt. Bird, Mt. Terror and Hut Point Peninsula on Ross Island are radially distributed at $120^{\circ}$ around Erebus (Kyle et al., 1992), indicating generation of large volumes of parental basanite beneath Erebus, at the base of the thin ( $20 \mathrm{~km}$; Bannister et al., 2003) crust on which it is built. This supports the hypothesis that large quantities of mantle are required to account for the voluminous production of 
anorthoclase phonolite by differentiation (Kyle et al., 1992) and requires mantle upwelling, either as a $\geq 40-\mathrm{km}$ wide plume (Kyle et al., 1992) or via decompression melting of (metasomatised) mantle during intraplate strike-slip tectonics ( [Rocchi et al., 2002], [Rocchi et al., 2003] and [Rocchi et al., 2005]).

One feature that makes Erebus particularly interesting from a degassing perspective is the evidence for extensive differentiation of magmas. Lavas on the upper parts of Erebus volcano are composed predominantly of anorthoclase-phyric tephriphonolite and phonolite compositions (Kyle et al., 1992). Indeed, those erupted during the last 17 ka have a remarkably stable bulk phonolitic composition (Kelly et al., 2008). However, basanite, phonotephrite, and plagioclase-bearing tephriphonolite lavas crop out in eroded volcanic cones that form islands and sea cliffs on the southwest side of Erebus volcano and Hut Point Peninsula ( [Kyle et al., 1992] and [Moore and Kyle, 1987]). Collectively, the lavas define a continuous fractionation series (referred to as the Erebus Lineage) from basanite to phonolite (Kyle et al., 1992).

Our principal aim here is to develop a coherent model for the magmatic plumbing system at Erebus. We analyse two principal datasets: surface observations of explosive versus passive degassing from the active lava lake, and the compositions and volatile contents of melt inclusions from a suite of Erebus Lineage and related rocks ranging from basanite to recently erupted anorthoclase phonolite bombs. The inclusion compositions mimic their associated whole rock chemistry, and document the evolution of the magmas. In light of the magmatic origin of $\mathrm{CO}_{2}$ emitted from Erebus (Werner and Brantley, 2003), we use the pre-eruptive volatile content of this fractional-crystallisation sequence to build a framework for understanding the $\mathrm{CO}_{2}$-dominated degassing of the magmatic system, and to interpret the composition of the emitted gas plume. Coupling of both deep and shallow signatures enables us to track volatile release right down to the lower lithospheric source of Erebus and its related volcanic centres. This provides valuable insights into the extent of degassing and its relationship with parental magmas at one of the world's most active intraplate alkaline volcanoes.

\section{Methods}

\subsection{Samples}

Samples for melt inclusion study were collected from Dry Valley Drilling Project (DVDP) cores extracted at Hut Point Peninsula (basanite), and from exposures on Inaccessible and Tent Islands (tephriphonolite), Turks Head (basanite, phonotephrite, tephriphonolite) and the summit of Erebus volcano (phonolite) (Moore and Kyle, 1987). A map of locations can be found in the Supplementary Material (Fig. 1). Samples DVDP 3-283, DVDP 3-295, AW82033, 7713, 97009, 97010, and 97011 are rapidly-quenched hyaloclastites with pristine melt inclusions. Sample 97006 is a highly vesicular lava-flow top. Sample 97018 is an anorthoclase phonolite bomb erupted in 1997, and EA1 is a crystal from a phonolite bomb. Only glassy inclusions lacking any signs of leaking or cracking were selected for study. Details of the samples and analyses of the whole rock samples are reported in Sections 1 and 2 of the Supplementary Material.

The concentrations of dissolved $\mathrm{H}_{2} \mathrm{O}$ and $\mathrm{CO}_{2}$ in melt inclusions were measured by FTIR spectroscopy using a Nicolet Magna 750 at the U.S. Geological Survey in Menlo Park. Melt inclusions were prepared as doubly polished wafers ranging in thickness from 25 to $200 \mu \mathrm{m}$. 
Transmission infrared spectra were collected in the $1200-4000 \mathrm{~cm}^{-1}$ range and measurements of total $\mathrm{H}_{2} \mathrm{O}$ (hydroxyl and molecular water) were made using the fundamental $\mathrm{O}-\mathrm{H}$ stretch feature at $3550 \mathrm{~cm}^{-1}$. Carbon dioxide was determined using the carbonate asymmetric stretch doublet near $1500 \mathrm{~cm}^{-1}$ and $1400 \mathrm{~cm}^{-1}$. Further details on analytical procedures are given in Section 3.1 of the Supplementary Material. The uncertainty of the total $\mathrm{H}_{2} \mathrm{O}$ and $\mathrm{CO}_{2}$ analyses for most samples is $\pm 11-12 \%$ and $\pm 15-50 \%$, respectively. Estimated uncertainties in $\mathrm{H}_{2} \mathrm{O}$ analyses are up to $\pm 25 \%$ for some inclusions from the phonotephrite and tephriphonolite samples. The uncertainty of the carbonate determinations for the volatile-rich samples (DVDP $3-295$, DVDP $3-283,97009$ ) is estimated to be $\pm 15 \%$. The quoted uncertainties are calculated from errors in the absorption peak height, inclusion thickness, density, and molar absorptivity. Replicate analyses of inclusions in DVDP 3-283a and DVDP 3-283b indicate reproducibility of better than $\pm 2 \%$ for both water and carbonate. Individual raw FTIR analyses, calculated physical properties, and computed $\mathrm{H}_{2} \mathrm{O}$ and $\mathrm{CO}_{2}$ abundances are reported in Tables 3, 4 and 6, respectively, of the Supplementary Material.

The concentrations of major elements and $\mathrm{S}, \mathrm{F}$ and $\mathrm{Cl}$ in the melt inclusions were determined using a Cameca SX-100 electron microprobe at New Mexico Tech (Section 3.2 and Table 6 of Supplementary Material). Glass analyses were obtained with a defocused 15-25 $\mu \mathrm{m}$ beam and a $10 \mathrm{nA}$ beam current and $15 \mathrm{kV}$ accelerating potential. Errors for analyses of glasses are $\pm 200 \mathrm{ppm}$ based on replicate analyses of standard glasses, except for fluorine whose errors are $\pm 1000 \mathrm{ppm}$.

\subsection{Open-path FTIR spectroscopy of lava lake emissions}

Open-path absorption spectra of the gas emissions were collected with a MIDAC Corporation M-4402-1 FTIR spectrometer sited on the crater rim, and using the lava lake as the infrared source, as described by Oppenheimer and Kyle (2008). Incoming radiation from the lake, $\sim 300 \mathrm{~m}$ line-of-sight distant, was collimated with a 10-inch Newtonian telescope, and all spectra were recorded with a nominal $0.5 \mathrm{~cm}^{-1}$ spectral resolution. Photographs of the lava lake and instrumental set-up are provided in the Supplementary Material (Section 4). The lava lake represents an unfaltering mid infrared radiation source while the very low humidity at the $\sim 3700 \mathrm{~m}$ above sea level crater result in exceptionally 'clean' absorption spectra (i.e., there is very little interference from atmospheric water vapour).

The measurements presented here were made in December 2005, a period when intermittent Strombolian eruptions were occurring in the lava lake (around three per day that partially emptied the lava lake, hurling bombs, some more than a metre across, up to a few hundred metres beyond the crater rim). We focus on retrievals of $\mathrm{H}_{2} \mathrm{O}, \mathrm{CO}_{2}$ and $\mathrm{CO}$, which were made from transformed interferograms (collected with a time step of $1 \mathrm{~s}$ ) using a code that simulates and fits atmospheric transmittance in discrete wavebands, specifically $2020-2100 \mathrm{~cm}^{-1}$ for $\mathrm{H}_{2} \mathrm{O}, \mathrm{CO}_{2}$ and $\mathrm{CO}$ (in addition to OCS). Uncertainties on these measurements are typically about $5 \%$ (e.g., Horrocks et al., 2001) but closer to $10 \%$ for measurements during explosions. Gas ratios are calculated from the raw column amounts after corrections are made for contributions of atmospheric water and $\mathrm{CO}_{2}$ (Oppenheimer and Kyle, 2008). For our purposes, the ratio of $\mathrm{CO}_{2} / \mathrm{CO}$ tracks redox conditions, while that of $\mathrm{CO}_{2} / \mathrm{H}_{2} \mathrm{O}$ relates to the source depth of degassing. Of particular relevance here, we were able to measure the gas released by exploding gas slugs during the Strombolian activity, allowing comparison with the passive gas emission. 


\subsection{Modelling}

The equilibrium saturation model used here was based on work of Moretti et al. (2003) for the $\mathrm{C}-\mathrm{O}-\mathrm{H}-\mathrm{S}$ system, and incorporated: (i) a regular mixture approach to $\mathrm{H}_{2} \mathrm{O}-\mathrm{CO}_{2}-$ melt saturation (Papale et al., 2006); (ii) polymeric treatment of silicate melts for computation of sulphur solubility and speciation ( [Moretti and Ottonello, 2005] and [Moretti and Papale, 2004]), and compatible oxidation state of iron in the melt ( [Moretti, 2005] and [Ottonello et al., 2001]); (iii) multiple gas-phase species' equations of state (Belonoshko and Saxena, 1992); and (iv) mass balances for total (exsolved + dissolved) $\mathrm{H}_{2} \mathrm{O}, \mathrm{CO}_{2}$ and S. All information is exchanged between the different modules, and composition and redox quantities are modified so as to zero model functions by means of a globally-convergent, nonlinear method. This procedure ensures internal consistency and, critical to the Erebus case, permits application of the model to a wide spectrum of silicate melts. We also included a code for FeS precipitation based on the exchange reaction (Moretti and Baker, 2008):

$\mathrm{FeO}($ melt $)+1 / 2 \mathrm{~S}_{2} \Leftrightarrow \mathrm{FeS}($ pyrrothite $)+1 / 2 \mathrm{O}_{2}$.

This locates the FeS saturation surface in $P-\mathrm{S}_{\text {melt }}-f \mathrm{O}_{2}$ space, and at relatively oxidised conditions for which dissolved sulphur, $S_{\text {melt }}$, is not only constituted of sulphide.

Papale et al. (2006) showed that $\mathrm{H}_{2} \mathrm{O}-\mathrm{CO}_{2}$ saturation modelling in melts produces uncertainties in pressure $(P)$ retrieval of up to $20 \%$ at $20 \mathrm{kbar}$, pertaining to the solubility database over which the model was calibrated. The maximum uncertainties on $f \mathrm{O}_{2}$ values computed by SCSS modelling are at most $0.3 \log$ units, reflecting uncertainties in the actual constitution of the FeS monosulphide solution. Note that any errors in $f \mathrm{O}_{2}$ would have the same direction, and so would not undermine the key findings reported below.

\section{Observations and analysis}

\subsection{Lava lake degassing}

The complex degassing of Erebus is characterised by passive emissions from its persistent lava lake, which are sporadically perturbed by Strombolian eruptions. The explosions are associated with low frequency seismic signals whose source centroid lies less than $\sim 400 \mathrm{~m}$ below, and several hundred metres west and north, of the lava lake surface (Aster et al., 2008). Passive degassing has been interpreted as a two-component mixing of a $\mathrm{CO}_{2}$-rich $\left(\sim 40 \mathrm{~mol} \%\right.$; mass $\left.\mathrm{CO}_{2}{ }^{\text {gas }} / \mathrm{H}_{2} \mathrm{O}^{\text {gas }}=1.8\right)$ "conduit gas" that percolates through a permeable magma-filled conduit with an $\mathrm{H}_{2} \mathrm{O}$-rich $(\sim 89 \mathrm{~mol} \%)$ gas exsolved near the lake surface when magma blobs episodically enter the lake (Oppenheimer et al., 2009). An oxygen fugacity below the quartz-fayalite-magnetite (QFM) buffer of $\sim$ QFM- $0.88 \log$ units characterises passive gas emissions $\left(\mathrm{CO}_{2} / \mathrm{CO} \sim 10\right.$ to 15 , temperature of $\left.1273 \mathrm{~K}\right)$, which corresponds very closely to the $f \mathrm{O}_{2}$ computed at surface pressure and $1273 \mathrm{~K}$ from mineral chemistry of Erebus phonolite (e.g. [Kelly et al., 2008] and [Oppenheimer and Kyle, 2008]). In contrast, explosively released gases are characterised by higher $\mathrm{CO}_{2}$ and lower $\mathrm{H}_{2} \mathrm{O}$ proportions (Table 1 and Fig. $1 ; \mathrm{CO}_{2}{ }^{\text {gas }} / \mathrm{H}_{2} \mathrm{O}^{\text {gas }} \sim 4.3$ by mass, based on the median value in Table 1 ). Most strikingly, the oxidation state of "explosive" gas emitted by Strombolian eruptions, computed from the average $\mathrm{CO}_{2} / \mathrm{CO}$ molar ratio of $\sim 65$ (based on the median value in Table 1 and at $1273 \mathrm{~K}$ ), indicates redox conditions close to the nickel-nickel oxide buffer (NNO). 


\subsection{Melt inclusions}

Large melt inclusions (20 to $350-\mu \mathrm{m}$-across) are abundant in olivine from basanites, phonotephrites and tephriphonolites. Melt inclusions in olivine from the phonolite samples 97018 and EA1 are small and so, for these samples, we focused on anorthoclase-hosted inclusions, which range from $<10$ to $>600 \mu \mathrm{m}$ across (see Fig. 2 in the Supplementary Material for photomicrographs). The average compositions for each sample are listed in Table 2; the full dataset of major, trace and volatile contents for individual inclusions is reported in Table 6 of the Supplementary Material.

With the exception of sample AW82033, the inclusions are all more evolved and have higher total alkalis compared with the host bulk rock compositions. Typically, compositions of melt inclusions represent residual liquids after crystallisation of mineral phases present in the bulk sample. Thus inclusions are depleted, relative to the bulk rock composition, in elements compatible with the mineral phases, and enriched in the elements incompatible in the minerals. Tie lines from the bulk rock to the melt inclusions reveal a classic liquid line of descent, which matches the overall trend for lavas on Erebus (Kyle et al., 1992). As some of the melt inclusions in AW82033 are compositionally less evolved (lower $\mathrm{SiO}_{2}$ ) than the host rock, it is likely that some olivines may be xenocrysts derived from a more mafic parent or that there was mixing of a more primitive magma into the system during the time the olivine was crystallising.

Water concentrations in melt inclusions show considerable scatter but with an overall decrease in abundance from basanite to phonolite (Table 2). In the DVDP basanites (3-283, 3-295), melt inclusion $\mathrm{H}_{2} \mathrm{O}$ contents range from 1.15 to $1.75 \mathrm{wt} . \%$, and have an average of $1.5 \mathrm{wt} . \%$. In the more evolved compositions, the $\mathrm{H}_{2} \mathrm{O}$ contents of melt inclusions are lower than those of the basanite. The inclusions from sample 97009 have an average of $0.5 \mathrm{wt} . \%$ $\mathrm{H}_{2} \mathrm{O}$, whereas in the other phonotephrite to phonolite samples, the inclusion $\mathrm{H}_{2} \mathrm{O}$ content is $\sim 0.1 \mathrm{wt} . \%$.

The melt inclusions vary widely in $\mathrm{CO}_{2}$ contents from 448 to $7300 \mathrm{ppm}$. The average $\mathrm{CO}_{2}$ contents of inclusions in the two DVDP basanite samples are similar, containing up to $7300 \mathrm{ppm}$. Melt inclusions in tephriphonolite (97009) range from 1500 to $3600 \mathrm{ppm} \mathrm{CO}_{2}$, and have an average of $2421 \pm 70 \mathrm{ppm} \mathrm{CO}_{2}$. The average $\mathrm{CO}_{2}$ concentration in inclusions contained in the other samples is lower, with a range from 448 to $1166 \mathrm{ppm}$ (Table 2). Inclusions with low $\mathrm{CO}_{2}$ contents correspond to those with low $\mathrm{H}_{2} \mathrm{O}$ contents. Nevertheless, we note that all inclusions contain appreciable quantities of water and $\mathrm{CO}_{2}$.

Sulphur contents of melt inclusions decrease systematically from $\sim 2200 \mathrm{ppm}$ in basanite to $\sim 370 \mathrm{ppm}$ in phonolite. There is a clear anti-correlation with the $\mathrm{SiO}_{2}$ content of the inclusions (Table 2). The sulphur contents of phonotephrite through phonolite show a linear relationship with FeO. However, the sulphur content of the basanite is higher than that of the phonotephrite, despite similar FeO contents. Iron sulphide globules (pyrrhotite), $<3 \mu \mathrm{m}$ in diameter, are present in inclusions from all samples, indicating saturation with respect to sulphide. 


\section{Discussion}

Here we evaluate and synthesise the evidence from both melt inclusions and surface degassing observations to build a new conceptual model for the magmatic plumbing system at Erebus.

\subsection{Imaging the plumbing system via volatile geobarometry}

On the $\mathrm{H}_{2} \mathrm{O}-\mathrm{CO}_{2}$ diagram (Fig. 2a), the melt inclusions define three distinct populations: Group 1 has high- $\mathrm{H}_{2} \mathrm{O}$ and relatively high- $\mathrm{CO}_{2}$ contents and belongs to the basanitic DVDP lineage, i.e., closest to the mantle source; Group 2 consists of tephriphonolitic inclusions with intermediate $\mathrm{H}_{2} \mathrm{O}$ abundance and high- $\mathrm{CO}_{2}$ contents, hence high saturation pressures, comparable to those of DVDP basanites; while Group 3 is composed of low- $\mathrm{H}_{2} \mathrm{O}$ and low$\mathrm{CO}_{2}$ (up to $\sim 2100 \mathrm{ppm}$ ) inclusions that span the compositional spectrum of the Erebus Lineage, i.e., from basanites to anorthoclase phonolites. This population also includes phonolite lava bombs expelled from the active summit crater of Erebus volcano during Strombolian explosions.

Application of the multi-component $\mathrm{H}_{2} \mathrm{O}-\mathrm{CO}_{2}$ saturation model of Papale et al. (2006) to each sample yields saturation pressures up to $8 \mathrm{kbar}$ for DVDP basanites, corresponding to depths of $\sim 25-30 \mathrm{~km}$ and therefore in the mantle. Surprisingly, the basanitic trend starting from this considerable depth is mimicked by sample 97009 with tephriphonolite-phonolite affinity (Fig. 2a) from pressures of $\sim 7.4 \mathrm{kbar}$ and continuously differentiating up to lava lake conditions. (Although the tephriphonolite melt inclusions contain less $\mathrm{CO}_{2}$, computed saturation pressures are similar to those for the basanites reflecting lower $\mathrm{CO}_{2}$ solubility in the more evolved magmas.) Such high saturation pressures suggest that the tephriphonolitic magmas differentiate, to a first approximation, at the mantle depths from which the parental basanite originates. Another intriguing point that emerges from Fig. 2a is that some basanites (AW82033) also contribute to Group 3 samples, representing saturation pressures from 2.5 to $0.36 \mathrm{kbar}$. Their occurrence shows that a magma, compositionally close to the parental one feeding the Erebus province, rose from deep lithospheric regions up to $\sim 0.36 \mathrm{kbar}$ without significant crystallisation (Fig. 2a and b). Meanwhile, recently erupted lava bombs of evolved phonolitic composition (samples 97018 and EA1) host melt inclusions recording saturation pressures down to $3 \mathrm{kbar}$.

Progressive dehydration is observed from Group 1 to Group 3 samples, together with a relative increase in dissolved $\mathrm{CO}_{2}$ with respect to dissolved $\mathrm{H}_{2} \mathrm{O}$ contents. Thus, these three populations cannot be explained by a simple degassing trend for a depressurizing system, either by open- or closed-system degassing. Were this the case, ascending magma batches should have evolved by continuously decreasing their $\mathrm{CO}_{2}{ }^{\text {melt }} / \mathrm{H}_{2} \mathrm{O}^{\text {melt }}$ ratio. Furthermore, if simple degassing accompanied magma ascent, it was evidently attended by extensive crystallisation. This would have enriched the melts with water because of its higher solubility. We therefore conclude that some of the voluminous crystallisation that leads from basanite to phonolite magmas is associated with only limited ascent of magma bodies, i.e., isobaric crystallisation is driven by the arrival of deep, $\mathrm{CO}_{2}$-dominated gas at various levels where magmas stagnate.

Model-computed $\mathrm{CO}_{2}{ }^{\text {gas }} / \mathrm{H}_{2} \mathrm{O}^{\text {gas }}$ mass ratios (Fig. 2c) also discriminate the three melt inclusion populations. The lowest ratios are related to the more deep-seated basanitic melt, whereas the deep-seated tephriphonolites (Group 2, 97009) display a roughly constant 
$\mathrm{CO}_{2}{ }^{\text {gas }} / \mathrm{H}_{2} \mathrm{O}^{\text {gas }}$ ratio of $\sim 200$ (by mass). At saturation pressures below $4 \mathrm{kbar}, \mathrm{CO}_{2}{ }^{\text {gas }} / \mathrm{H}_{2} \mathrm{O}^{\text {gas }}$ ratios reach up to 1000 . These then decrease with decreasing pressures, defining a trend that characterises the shallow melts. Melt inclusions from recent Erebus lava bombs are from relatively shallow depths, have low- $\mathrm{H}_{2} \mathrm{O}$ contents, and display among the highest $\mathrm{CO}_{2}{ }^{\text {gas }} / \mathrm{H}_{2} \mathrm{O}^{\text {gas }}$ ratios of the associated vapour phase (Fig. $2 \mathrm{c}$ ).

The observed dehydration coupled with increasing $\mathrm{CO}_{2} / \mathrm{H}_{2} \mathrm{O}$ ratios, both in the melt (Fig. 2a) and gas phases (Fig. 2c), points to extensive and pervasive gas fluxing (e.g., [Arienzo et al., 2010], [Barsanti et al., 2009], [Johnson et al., 2008], [Métrich et al., 2010] and [Spilliaert et al., 2006]; Vigouroux et al., 2008) through the entire plumbing system. The shift from one melt inclusion population to another suggests further that the crystallising and differentiating magma is continuously fluxed by a $\mathrm{CO}_{2}$-rich gas, providing strong evidence for the ascent through the plumbing system of a separated gas phase originating from considerable lithospheric depths. This conclusion is consistent with gas flux measurements at the surface and with oxygen isotope data (Kelly et al., 2008). Polybaric fluxing seems to be particularly effective for the intermediate tephriphonolitic Group 2 (sample 97009; Fig. 2a), depressurizing from $\sim 7-8$ to $\sim 4$ kbar with a $\mathrm{CO}_{2}{ }^{\text {gas }} / \mathrm{H}_{2} \mathrm{O}^{\text {gas }}$ ratio of 200 (Fig. 2c), which is likely to represent a gas released at pressures greater than $8 \mathrm{kbar}$, close to the point of first exsolution of a $\mathrm{H}_{2} \mathrm{O}-\mathrm{CO}_{2}$ saturated basanite sourced by partial melting of pyrolitic mantle (Orlando et al., 2000).

In the case of Group 3 inclusions, the open-system fluxing of $\mathrm{CO}_{2}$-rich fluids through magma residing at various levels can be seen as the result of a continuous separation process in the magma column from $\sim 4 \mathrm{kbar}$ (i.e., $\sim 15 \mathrm{~km}$ depth) upwards, which produces the observed jump in $\mathrm{CO}_{2}{ }^{\text {gas }} / \mathrm{H}_{2} \mathrm{O}^{\text {gas }}$ ratios (up to $800-1000$ by mass; Fig. 2c). Note, too, the evidence for deep $\mathrm{CO}_{2}$ in melt inclusion analyses for the recently erupted phonolite lava bomb (EA1), which has a $\mathrm{CO}_{2}{ }^{\text {gas }} / \mathrm{H}_{2} \mathrm{O}^{\text {gas }}$ ratio of $\sim 800$ at $P=120$ bar (Fig, 2c). Crystallisation induced by gas fluxing further aids increase of pressure, because of sealing the magmatic system, and hence tends to further increase carbon dioxide abundance in the gas phase (e.g., Blundy et al., 2010).

The considerable crystallisation from basanite to phonolite could result from elevation of solidus temperatures of magmas due to dehydration induced by $\mathrm{CO}_{2}$ dominated gas fluxing ( [Blundy and Cashman, 2008], [De Natale et al., 2004] and [Trigila and De Benedetti, 1993]). In this way, fluxing through a relatively static magma column beneath Erebus produces extensive crystallisation and differentiation much more efficiently than degassing of magma batches that separate the exsolved gas phase on ascent (e.g. [Collins et al., 2009] and [Quareni et al., 2007]). Crystallisation upon fluxing is consistent with the general $\mathrm{H}_{2} \mathrm{O}$-loss observed from Group 1 to Group 3 melt inclusions.

\subsection{From depth to surface: magmatic evolution and passive/explosive degassing}

The next question concerns the relation between the gas discharged at the surface today and the deep magmatic gas inferred from the melt inclusions. Considering the sustained, passively released gas emission from the lava lake, we note first that the wide compositional spectrum of samples from Group 3 melt inclusions, from basanite to phonolite, extends along the same trajectory of decreasing $\mathrm{CO}_{2}{ }^{\text {gas }} / \mathrm{H}_{2} \mathrm{O}^{\text {gas }}$ (Fig. 2c). Also, the fluid phase $\mathrm{CO}_{2}{ }^{\text {gas }} / \mathrm{H}_{2} \mathrm{O}^{\text {gas }}$

associated with the melt inclusions is remarkably higher than the $\mathrm{CO}_{2} / \mathrm{H}_{2} \mathrm{O}$ observed by openpath FTIR spectroscopy for both passive and explosive gas emissions. The $\mathrm{CO}_{2}{ }^{\text {gas }} / \mathrm{H}_{2} \mathrm{O}^{\text {gas }}$ ratio decreases with decreasing pressure (Fig. 2c), suggesting that volatile release along typical 
closed- or open-system degassing paths associated with ascending magmas becomes effective only in the upper part ( $<4 \mathrm{kbar}$ ) of the plumbing system. The "conduit gas" composition $\left(\mathrm{CO}_{2}{ }^{\text {gas }} / \mathrm{H}_{2} \mathrm{O}^{\text {gas }}=1.78\right)$ cannot be achieved by simple closed-system degassing of $\mathrm{CO}_{2-}$ enriched magmas, unless gas separation occurs at pressures less than 10 bar. Much more likely, degassing in open system conditions (Fig. 2c) becomes effective within these shallow bodies, favoured by convection and high permeability. Degassing coupled with fractional crystallisation, in this case leading to dissolved $\mathrm{H}_{2} \mathrm{O}$-enrichment, yields the observed "conduit gas" $\mathrm{CO}_{2}{ }^{\text {gas }} / \mathrm{H}_{2} \mathrm{O}^{\text {gas }}$ ratio between 30 and 40 bar (Fig. 2c), corresponding to a depth of $\sim 150 \mathrm{~m}$. Above this level, gas decouples and ascends by percolating through permeable conduit magma in the conduit (Oppenheimer et al., 2009).

The $\mathrm{CO}_{2}{ }^{\text {gas }} / \mathrm{H}_{2} \mathrm{O}^{\text {gas }}$ of explosive emissions necessarily demands the addition of $\mathrm{CO}_{2}$ into the system, (fluxing), which, in turn, reflects either (i) mixing, at very shallow levels, of nearly pure $\mathrm{CO}_{2}$ fluids rising from great depth with the conduit gas (bubble-only ascent), or (ii) closed-system degassing of volatile-rich magma blobs produced upon injection of these deep $\mathrm{CO}_{2}$-rich fluids into the shallow system, represented by melt compositions of Group 3 (twophase, melt-gas ascent). The first scenario is reminiscent of trends observed at open-conduit volcanoes such as Stromboli and Etna ( [Aiuppa et al., 2007], [Aiuppa et al., 2010] and [Shinohara et al., 2008]); in the Erebus case, the explosive gas composition can be manufactured with $\sim 50 \mathrm{wt}$.\% of the deep, almost $\mathrm{CO}_{2}$-pure, gas (Fig. 2c).

The second scenario implies the presence of progressively $\mathrm{CO}_{2}$-enriched gas and melt compositions reflecting accumulation of deep $\mathrm{CO}_{2}$ bubbles at pressures $<4 \mathrm{kbar}$, shifting the gas-phase composition to higher $\mathrm{CO}_{2}{ }^{\text {gas }} / \mathrm{H}_{2} \mathrm{O}^{\text {gas }}$ ratios (Fig. 2c). In fact, addition of deep $\mathrm{CO}_{2}-$ rich fluids to any of the melt compositions of Group 3, including modern Erebus phonolites, readily yields a magma with a total volatile ratio, $\mathrm{CO}_{2}{ }^{\mathrm{T}} / \mathrm{H}_{2} \mathrm{O}^{\mathrm{T}} \sim 4$, which can source the observed bulk degassing composition at atmospheric pressure. In the second scenario, fluxing defines a family of possible degassing trends that can be delineated on the $\mathrm{H}_{2} \mathrm{O}-\mathrm{CO}_{2}$ diagram by two extreme, closed system degassing trends for the melt inclusion compositions encountered (Fig. 2a). The upper boundary on the left of the figure represents the saturation line for a fixed $\mathrm{CO}_{2}{ }^{\mathrm{T}} / \mathrm{H}_{2} \mathrm{O}^{\mathrm{T}} \sim 4$ of magma blobs associated with the explosive emissions.

In both cases above (gas only versus melt-gas ascent), as well as for intermediate scenarios, gas fluxing is the prevalent process, and the plumbing system is only secondarily affected by upward magma transfer. Accumulation of $\mathrm{CO}_{2}$-rich bubbles reflects a supply from depth either as a separated gas phase or associated with episodic injection of basanite batches (AW82033-like) via a crustal 'nozzle' that favours passage of gas over melt. These batches would contribute to the shallow magma budget, with rapid fluxing leading to differentiation to the typical phonolites erupted by Erebus for $17 \mathrm{ka}$ or more. We note also that the presence of large mantle xenoliths in volcanic rocks from Ross Island and neighbouring volcanoes ( [Gamble et al., 1988], [Kyle et al., 1987] and [Stuckless and Ericksen, 1976]), including White Island, a shield volcano belonging to the Erebus Province (Cooper et al., 2007), suggests that basanitic magma formed in the upwelling mantle can rise rapidly to shallow levels, without appreciable residence in crustal magma chambers (Cooper et al., 2007). The variability recorded by $\mathrm{Nd}, \mathrm{Sr}, \mathrm{Hf}$ and particularly $\mathrm{Pb}$ isotopes between the (older) Erebus Lineage and DVDP basanites and phonotephrites, and the younger phonolitic lavas and bombs reinforces this possibility, suggesting efficient mixing of the parental basanites in a large magma chamber as a probable explanation for the observed Erebus isotopic compositions (Sims et al., 2008). 
The interplay of degassed magma overturn and gas fluxing allows both open-system degassing conditions, yielding the conduit gas feeding the normal degassing activity, and the production of magma blobs or gas slugs that, after fluid injection, ascend and source the Strombolian explosions. In the separation of gas within the conduit during open-system gas loss, fractional crystallisation up to low pressures (30-40 bar) plays a role in shifting the $\mathrm{CO}_{2}{ }^{\text {gas }} / \mathrm{H}_{2} \mathrm{O}^{\text {gas }}$ ratio towards more residual, hence water-rich, conditions (see open system trend shown in Fig. 2a).

\subsection{Redox conditions}

The evidence for gas fluxing and injection of deep fluids into shallow ( $P<4$ kbar) magma bodies that are either basanitic or differentiated up to phonolite, although useful in deciphering the role played by $\mathrm{CO}_{2}$-dominated gas ascending from depth, cannot explain the differences in redox signatures between the gases issued during passive and explosive activity (Table 1 and Fig. 1). Fortunately, further constraints on the deep gas phase can be obtained by inspecting sulphur behaviour at Erebus. Iron sulphides coexist with the melt phase in all the melt inclusion samples, indicating that degassing and magma differentiation occur along the sulphide saturation boundary at all depths. While this precludes adoption of bulk degassing arguments to estimate the total amount of sulphur, $\mathrm{S}^{\text {TOT }}$, from explosive gas emissions, it provides valuable information on the evolution of redox conditions along the rock lineage, because it constrains both $f \mathrm{O}_{2}$ and $f \mathrm{~S}_{2}$ along a univariant boundary for a given melt composition at a given temperature and pressure on the basis of Reaction (1) and:

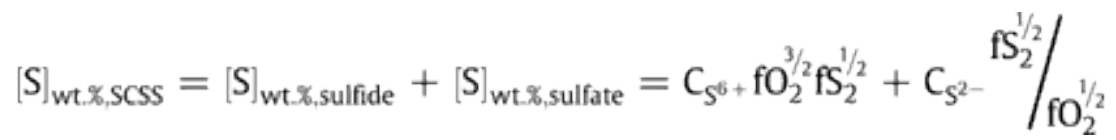

(e.g., Moretti and Ottonello, 2005) where $\mathrm{C}_{\mathrm{S}}{ }^{6+}$ and $\mathrm{C}_{\mathrm{S}}{ }^{2-}$ are the so-called sulphide- and sulphate-capacity of the melt. Eqs. (1) and (2) represent a system with two variables $\left(f \mathrm{O}_{2}\right.$ and $f \mathrm{~S}_{2}$ ) that can be used to compute FeS saturation conditions in basanitic to phonolitic melts (Fig. 3; Moretti and Baker, 2008). The analysed melt sulphur concentration, corresponding to the Sulphur Content at Sulphide Saturation (SCSS), is best reproduced by setting $\mathrm{fO}_{2}$ conditions that linearly decrease with pressure from $\mathrm{NNO}+0.4$ at 8 kbar to $\mathrm{NNO}-0.6$ at $1 \mathrm{bar}$, a trend that is consistent with the observations from measured gas compositions (Table 1).

The SCSS computed from anorthoclase-hosted melt inclusions in recently erupted lava bombs (971081 and EA1) requires $f_{2}$ values around $\mathrm{NNO}$ (Fig. 3); i.e., precisely in line with those computed from the $\mathrm{CO}_{2} / \mathrm{CO}$ ratio of explosive gas emissions measured by open-path FTIR spectroscopy at the crater rim. We can exclude the possibility that this is merely a coincidence due to $P-f \mathrm{O}_{2}-f \mathrm{~S}_{2}$ biases inherent in the model of Moretti and Baker (2008) since the model capability of predicting the redox state of hydrous phonolites at various values of $P$ and $f \mathrm{O}_{2}$ has been demonstrated by experimental determinations (Schuessler et al., 2008), and since the large compositional range covered by the Erebus magmas is encompassed by the calibration of the SCSS model. The analysis of SCSS thus yields compelling independent evidence that shallow and differentiated 97108- and EA1-hosted melt inclusions are associated with Strombolian gas emissions, which in turn probe the fluid signature of a more oxidised and deeper portion of the plumbing system, likely to be located at depths corresponding to $P>2.5 \pm 0.5 \mathrm{kbar}$. The SCSS of other melt inclusion compositions follow the expected trend 
of decreasing $f \mathrm{O}_{2}$, compatible with the redox state observed for the "conduit gas" (passive degassing).

Merging melt inclusion and gas emission data reveals that $f \mathrm{O}_{2}$ decreases with decreasing depth, the most reduced conditions being achieved in the lava lake. While we cannot yet determine the redox buffer of the system, the changes in oxidation state experienced as pressure decreases should reflect continuous $f \mathrm{O}_{2}$ readjustments following magma differentiation by crystal fractionation and re-equilibration with the surrounding rocks. For example, titanomagnetite is commonly found in inclusions throughout the Erebus lineage and occurs commonly as phenocrysts or dispersed in the groundmass ( [Kelly et al., 2008] and [Kyle et al., 1992]). We suggest that the continuous crystallisation of olivine and pyroxenes, with increasing Fe contents, and magnetite precipitation, may fix the activities of both $\mathrm{FeO}$ and $\mathrm{Fe}_{2} \mathrm{O}_{3}$, hence acting as the main redox buffer for $f \mathrm{O}_{2}$ through the whole plumbing system. Indeed, a linear decrease of $\mathrm{FeO} / \mathrm{Fe}_{2} \mathrm{O}_{3}$ is computed with decreasing pressure and increasing degree of magmatic differentiation (Fig. 4), whereas the $\mathrm{FeO} / \mathrm{Fe}_{2} \mathrm{O}_{3}$ activity ratio is roughly constant, at $\sim 4$. (We note that in glass-making this behaviour corresponds to the well-known effect of iron oxidation on alkali addition to glasses; e.g., Ottonello et al., 2001, and references therein.) Strombolian slugs preserve the higher $\mathrm{fO}_{2}$ of their source region likely through fast transfer and ascent in a closed-system up to the surface.

One question that remains is why the lava lake is even further reduced. Following the argument that iron is the predominant redox buffer, we suspect that crystallisation of magnetite in the lava lake and very shallow part of the conduit is responsible for the observed oxidation state of the lava lake:

$\mathrm{FeO}(\mathrm{liq})+\mathrm{Fe}_{2} \mathrm{O} 3\left(\right.$ liq) $\rightarrow \mathrm{Fe}_{3} \mathrm{O} 4$ (magnetite).

According to the oxidation state model incorporated in the method of Moretti and Baker (2008; and see references therein), just $\sim 1 \mathrm{wt} . \%$ crystallisation of magnetite (which is less than the measured contents in Erebus bombs) would shift $\mathrm{Fe}^{2+} / \mathrm{Fe}^{3+}$ enough to account for a $\log$ unit drop in $f \mathrm{O}_{2}$.

\section{Summary and conclusions}

We have reconciled volatile data representing the entire plumbing system of Erebus volcano, and of its associated older and peripheral volcanic centres, with observed gas emissions from the active lava lake. We have shown that deep gas transfer characterises the shallow activity, possibly explaining the observed eruptive style, switching from passive degassing to intermittent Strombolian explosions in which the deep and more oxidised gas component is discharged. Two mechanisms (bubble-only versus melt-gas ascent) may reconcile the two principal observations of explosive emissions: the relatively low $\mathrm{CO}_{2}{ }^{\text {gas }} / \mathrm{H}_{2} \mathrm{O}^{\text {gas }}$ ratio (4.2 by mass) and the apparent oxidation state (around NNO), which is typical of deep fluids at $P>4$ kbar. In the first case, mixing between the deep gas and shallow-derived gas would yield large gas bubbles (or slugs) rising through the uppermost part of the magma column as a decoupled, oxidised, single phase system. On reaching the lake surface, these rupture, recycling some of the phonolite magma stagnating and crystallising there under progressively reducing conditions (below QFM), thus restoring the oxidised gas redox signature $(\sim \mathrm{NNO})$ found in lava bomb-hosted melt inclusions. In the second case, volatile-rich and oxidised magma blobs are extracted at depths corresponding to pressures between 2 and $4 \mathrm{kbar}$, in good agreement with SCSS data on lava bomb melt inclusions. 
Rocks encountered en route to the surface could affect the chemistry of discharged gases by redox buffering. However, these rocks formed from the same magmatic system, which shows a clear trend of reducing upwards (Fig. 3). Furthermore, based on stable carbon isotope data (Werner and Brantley, 2003), we consider that any potential contribution of $\mathrm{CO}_{2}$ due to the breakdown of basement carbonates (if present) is negligible.

The picture that emerges (Fig. 5) from our integrated modelling of saturation properties $(P$, $\left.\mathrm{CO}_{2}{ }^{\text {gas }} / \mathrm{H}_{2} \mathrm{O}^{\text {gas }}\right)$ and redox conditions $\left(f \mathrm{O}_{2}, \mathrm{FeO} / \mathrm{Fe}_{2} \mathrm{O}_{3}\right)$, is of a complex volcanic system in which magmas evolve from the mantle under steady-state fluxing of $\mathrm{CO}_{2}$-rich fluids, resulting in $\mathrm{CO}_{2}$-enrichment and dehydration up to shallow levels $(P<3-4 \mathrm{kbar})$. At these pressures, gases re-equilibrate in magmas and are subsequently discharged with a "conduit" composition through the lava lake, or as explosive slugs that rapidly rise through the shallow system retaining the signature of deeper and more oxidised (NNO) conditions while mixing with the conduit-derived gas. In both cases, the upper-level magmatic system at Erebus receives only limited magma resupply despite its continuous degassing (Kelly et al., 2008). Convection of a shallow reservoir, which is occasionally fed by deep basanites and continuously fluxed by the separated $\mathrm{CO}_{2}$-rich gas, ensures steady state conditions of the uppermost portions of the volcanic plumbing system, particularly the persistent lava lake.

Deep degassing from the parental basanite and the rise of separated $\mathrm{CO}_{2}$-rich fluid explain why degassing of phonolite constitutes only a fraction of the observed gas flux (Oppenheimer and Kyle, 2008). This also agrees with the lack of GPS evidence for endogenous growth of the volcanic edifice (Murray et al., 2006), which would be expected were there significant shallow-level magma injection and degassing. Assuming a total $\mathrm{CO}_{2}$ content, $\mathrm{CO}_{2}^{\mathrm{T}}$, of $6300 \mathrm{ppm}$ (based on Group 1 samples), the observed $\mathrm{CO}_{2}$ flux requires complete degassing of $\sim 1 \mathrm{~m}^{3} \mathrm{~s}^{-1}$ of basanite magma (Oppenheimer and Kyle, 2008). This is likely to be an underestimate, given that there are diffuse $\mathrm{CO}_{2}$ emissions from the volcano's flanks (Werner and Brantley, 2003) and that the total amount of available $\mathrm{CO}_{2}$ should be closer to that computed from the conduit gas composition, i.e. $3000 \mathrm{ppm}$.

The great depths of gas-liquid separation, together with the evidence of limited magma supply to the lava lake (Oppenheimer et al., 2009) and its persistence, lead us to suggest that geometrical or structural controls drive the differentiation process from basanite to anorthoclase phonolite throughout the entire plumbing system, i.e., from the degassing lithospheric mantle up to the surface. Consistent with the $\mathrm{CO}_{2}$-enrichment upon gas-magma fluxing, this control might be associated with the opening of crustal fractures, driven by the release of overpressures associated with the accumulation of deep fluids. Such overpressures can represent up to $30 \%$ of the lithostatic load in alkaline magmatic provinces where $\mathrm{CO}_{2}$ is abundant at depth (Lensky et al., 2006).

The persistence of the Erebus lake suggests bi-directional magma flow in the supply conduit (Oppenheimer et al., 2009), driven by density contrasts that arise principally from degassing. The feasibility of gas fluxing in sustaining the steady-state dynamics of lava lakes is supported experimentally (Witham et al., 2006). The occurrence of Strombolian activity at Erebus and its association with volatile-rich fluids of deep origin $(P>4 \mathrm{kbar})$ indicates the prevalence of both regimes (gas fluxing and input of volatile-rich blobs) in sustaining the Erebus lava lake. 


\section{1. mantle degassing of $\mathrm{CO}_{2}$}

Our investigation reveals Erebus volcano to be a large pump of mantle $\mathrm{CO}_{2}$, from depths corresponding to pressures of at least $8 \mathrm{kbar}$. Considering that basanite-hosted, plagioclasebearing lherzolitic nodules are found around the Ross Sea and Embayment area ( [Cooper et al., 2007], [Wysoczanski et al., 1995] and [Zipfel and Wörner, 1992]), our melt inclusionbased geobarometry is consistent with synthesis of a five-phase lherzolite with plagioclase and spinel from a pyrolitic assemblage between $4.5 \mathrm{kbar}$ at $1100{ }^{\circ} \mathrm{C}$ and $11.2 \mathrm{kbar}$ at $1200{ }^{\circ} \mathrm{C}$ ( [Cooper et al., 2007] and [Green and Hibberson, 1970]). Together with our estimate, these values encompass the relatively low-pressure range expected for mantle upwelling on lithospheric thinning (or vice-versa), which is most pronounced beneath the Ross Embayment (Bannister et al., 2003).

A continuous gas supply from a $\mathrm{CO}_{2}$-rich mantle source is typical of other intraplate volcanoes. Nyiragongo volcano (Democratic Republic of Congo) has a highly alkaline (nephelinite) lava lake and emits $\mathrm{CO}_{2}$ in quantities exceeding those that could be sustained by the erupted magma (Sawyer et al., 2008). Other volcanoes found in intraplate continental rifts are inferred to have a crustal $\mathrm{CO}_{2}$-dominated fluid-phase originating from partial melting in the mantle (Fig. 2a and c [Bailey, 1985], [Cooper et al., 2007] and [Foley et al., 2006]; [Santosh and Omori, 2008], [Werner and Brantley, 2003] and [Wörner, 1999]). We suggest that at these intraplate alkaline volcanoes, eruptions may occur even in the absence of significant changes to the local-to-regional stress state and can be triggered by the addition of volatile-rich magma from deep parental sources located at the crust-mantle transition or even below it. Addition of fluids arises from pervasive gas fluxing through relatively stationary plumbing systems, and reflects the volatile enrichment of the source from which fluids are released.

The conceptual volcanological model developed here through tracking gas-melt saturation properties from the mantle upwards can be generalised to intraplate alkaline volcanoes, including (i) the oxidised conditions of the mantle source, (ii) the progressive reduction upwards, and (iii) the continuous saturation with sulphides, probably representing immiscible liquids at mantle depth (Andersen et al., 1987). The ensemble of these features, revealed here by melt inclusions and surface observations, may be typical of rifting mantle, as has previously been identified based on studies of peridotite xenoliths from the Jetty Peninsula (East Antarctica; Foley et al., 2006). For the more oxidised xenoliths in particular, a dominant role of $\mathrm{CO}_{2}$ is suggested by the abundance of carbonates as inclusions in rock-forming minerals (Foley et al., 2006). A $\mathrm{CO}_{2}$-rich oxidising environment has also been confirmed by experiments (Foley et al., 1986), and claimed by Chakrabarti et al. (2009) as responsible for ultrasodic and potassic products of Nyiragongo, some of whose lavas have a groundmass $\mathrm{CaCO}_{3}$ content of up to 11.9 wt.\% (Sahama, 1978, as quoted in Chakrabarti et al., 2009).

Mantle gas fluxing through the crust also explains why, at intraplate alkaline volcanoes, the large $\mathrm{CO}_{2}$ fluxes measured at vents are not balanced by the rates and volumes of observed volcanism. If the possibility of diffuse emissions from volcano flanks is considered, the contribution of deep $\mathrm{CO}_{2}$ from intraplate magmatic volcanoes may be even greater than we think. For Erebus, melt inclusions in tephriphonolites (Fig. 2b) record depths comparable to those estimated for the parental basanites, testifying to pervasive mantle $\mathrm{CO}_{2}$-degassing. This may represent an important and little considered source to the troposphere, emphasising further the solid Earth's influence on the state of the atmosphere and climate. 
Finally, we suggest that a better appraisal of the role and significance of $\mathrm{CO}_{2}$-rich fluid fluxing within the context of contrasting plume (Kyle et al., 1992) versus rift-related decompression melting hypotheses ( [Cooper et al., 2007], [Rocchi et al., 2002] and [Rocchi et al., 2005]), can make a significant contribution toward deciphering the history and evolution of volcanism in the Southern Ross Sea area.

\section{Acknowledgements}

Fieldwork was supported by grantsANT-0538414 and ANT-0838817 from the Office of Polar Programs (National Science Foundation). CO thanks the Leverhulme Trust for a Fellowship, and the European Research Council (DEMONS project) and NERC National Centre for Earth Observation for funding. Le Studium receives support from the European Regional Development Fund. RM acknowledges financial support from PRIN 2007 funds of the Ministry of University and Research of the Italian Government. We thank Bruno Scaillet and Michel Pichavant for discussions, Don Mullally and Pete Zemek at MIDAC for FTIR support, Mike Burton for the infrared retrieval code, and Bill McIntosh and Nelia Dunbar for collaboration in the fieldwork. We are very grateful to Jon Blundy and an anonymous referee for comments that led to significant improvements to the original manuscript, and to Richard Carlson for his editorial supervision and advice.

A. Aiuppa, R. Moretti, C. Federico, G. Giudice, S. Gurrieri, M. Liuzzo, P. Papale, H. Shinohara, M. Valenza Forecasting Etna eruptions by real-time observation of volcanic gas composition Geology, 35 (2007), pp. 1115-1118

Aiuppa et al., 2010 A. Aiuppa, A. Bertagnini, N. Métrich, R. Moretti, A. Di Muro, M. Liuzzo, G. Tamburello A degassing model for Stromboli volcano Earth Planet. Sci. Lett., 295 (2010), pp. 195-204

Andersen et al., 1987 T. Andersen, W.L. Griffin, S.Y. O'Reilly Primary sulphide melt inclusions in mantle-derived megacrysts and pyroxenites Lithos, 20 (1987), pp. 279-294

Arienzo et al., 2010 I. Arienzo, R. Moretti, L. Civetta, L. Orsi, P. Papale The feeding system of the Agnano-Monte Spina eruption (Campi Flegrei, Italy): dragging the past into present activity and future scenarios Chem. Geology, 270 (2010), pp. 135-147 http://dx.doi.org/10.1016/j.chemgeo.2009.11.012

Aster et al., 2008 R. Aster, D. Zandomeneghi, S. Mah, S. McNamara, D.B. Henderson, H. Knox, K. Jones Moment tensor inversion of very long period seismic signals from Strombolian eruptions of Erebus Volcano J. Volcanol. Geotherm. Res., 177 (2008), pp. 635-647

Bailey, 1985 D.K. Bailey Fluids, melts, flowage and styles of eruption in alkaline ultramafic magmatism Trans. Geol. Soc. S. Afr., 88 (1985), pp. 449-457

Bannister et al., 2003 S. Bannister, J. Yu, B. Leitner, B.L.N. Kennett Variations in crustal structure across the transition fromWest to East Antarctica, Southern Victoria Land Antarctica. Geophys. J. Int., 155 (2003), pp. 870-884

Barsanti et al., 2009 M. Barsanti, P. Papale, D. Barbato, R. Moretti, E. Hauri, E. Boschi, A. Longo Heterogeneous large total $\mathrm{CO}_{2}$ abundance in the shallow magmatic system of 
Kilauea volcano Hawaii. J. Geophys. Res., 114 (2009), p. B12201

http://dx.doi.org/10.1029/2008JB006187

Belonoshko and Saxena, 1992 A. Belonoshko, S.K. Saxena A molecular dynamics study of pressure-volume-temperature properties of super-critical fluids: $1 . \mathrm{H}_{2} \mathrm{O}$ Geochim. Cosmochim. Acta, 55 (1992), pp. 381-387

Blundy and Cashman, 2008 J. Blundy, K. Cashman Petrologic reconstruction of magmatic system variables and processes Rev. Mineral. Geochem., 69 (2008), pp. 179-239

Blundy et al., 2010 J. Blundy, K.V. Cashman, A. Rust, F. Witham A case for $\mathrm{CO}_{2}$-rich arc magmas Earth Planet. Sci. Lett., 290 (2010), pp. 289-301

Chakrabarti et al., 2009 R. Chakrabarti, A.R. Basu, A.P. Santo, D. Tedesco, O. Vaselli Isotopic and geochemical evidence for a heterogeneous mantle plume origin of the Virunga volcanics, Western rift, East African Rift system Chem. Geol., 259 (2009), pp. 273-289

Collins et al., 2009 S.J. Collins, D.M. Pyle, J. Maclennan Melt inclusions track preeruption storage and dehydration of magmas at Etna Geology, 37 (2009), pp. 571-574

Cooper et al., 2007 A.F. Cooper, J.A. Lotte, R.F. Coulter, G.N. Eby, W.C. McIntosh Geology, geochronology and geochemistry of a basanitic volcano, White Island, Ross Sea Antarctica. J. Volcanol. Geotherm. Res., 165 (2007), pp. 189-216

De Natale et al., 2004 G. De Natale, C. Troise, R. Trigila, D. Dolfi, C. Chiarabba Seismicity and 3-D substructure at Somma-Vesuvius volcano: evidence for magma quenching, Earth Planet Sci. Lett., 221 (2004), pp. 181-196

Foley et al., 1986 S.F. Foley, W.R. Taylor, D.H. Green The role of fluorine and oxygen fugacity in the genesis of the ultrapotassic rocks Contrib. Mineral. Petrol., 94 (1986), pp. 183-192

Foley et al., 2006 S.F. Foley, A.V. Andronikov, D.E. Jacob, S. Melzer Evidence from Antarctic mantle peridotite xenoliths for changes in mineralogy, geochemistry and geothermal gradients beneath a developing rift Geochim. Cosmochim. Acta, 70 (2006), pp. 3096-3120

Gamble et al., 1988 .A. Gamble, F. McGibbon, P.R. Kyle, M.A. Menzies, I. Kirsch Metasomatised xenoliths from Foster Crater, Antarctica: implications for lithosphere structure and processes beneath the Transantarctic Mountain front J. Petrol., Special Lithosphere Issue (1988), pp. 109-138

Giggenbach et al., 1973 W.F. Giggenbach, P.R. Kyle, G. Lyon Present volcanic activity on Mt. Erebus, Ross Island, Antarctica Geology, 1 (1973), pp. 135-136

Green and Hibberson, 1970 D.H. Green, W. Hibberson The instability of plagioclase in peridotite at high pressure Lithos, 3 (1970), pp. 209-221 
Horrocks et al., 2001 L.A. Horrocks, C. Oppenheimer, M.R. Burton, H.R. Duffell, N.M. Davies, N.A. Martin, W. Bell Open-path Fourier transform infrared spectroscopy of $\mathrm{SO}_{2}$ : an empirical error budget analysis, with implications for volcano monitoring J. Geophys. Res., 106 (2001), pp. 27647-27659

Johnson et al., 2008 E.R. Johnson, P.J. Wallace, K.V. Cashman, H.D. Granados, A.J.R. Kent Magmatic volatile contents and degassing-induced crystallization at Volcàn Jorullo, Mexico: implications for melt evolution and the plumbing systems of monogenic volcanoes Earth Planet. Sci. Lett., 269 (2008), pp. 478-487

Kelly et al., 2008 P.J. Kelly, P.R. Kyle, N.W. Dunbar, K.W.W. Sims Geochemistry and mineralogy of the phonolite lava lake, Erebus volcano, Antarctica: 1972-2004 and comparison with older lavas J. Volcanol. Geotherm. Res, 177 (2008), pp. 589-605

Kyle et al., 1987 P.R. Kyle, A. Wright, I. Kirsch Ultramafic xenoliths in the late Cenozoic McMurdo Volcanic Group, western Ross Sea embayment, Antarctica P.H. Nixon (Ed.), Mantle Xenoliths, John Wiley \& Sons (1987), pp. 287-293

Kyle et al., 1992 P.R. Kyle, J.A. Moore, M.F. Thirlwall Petrologic evolution of anorthoclase phonolite lavas at Mount Erebus, Ross Island, Antarctica J. Petrol., 33 (1992), pp. 849-875

Lensky et al., 2006 N.G. Lensky, R.W. Niebo, J.R. Holloway, V. Lyakhovsky, O. Navon Bubble nucleation as a trigger for xenolith entrapment in mantle melts Earth Planet. Sci. Lett., 245 (2006), pp. 278-288

Métrich et al., 2010 N. Métrich, A. Bertagnini, A. Di Muro Conditions of magma storage, degassing and ascent at Stromboli: new insights into the volcano plumbing system with inferences on the eruptive dynamics J. Petrol., 51 (2010), pp. 603-626

Moore and Kyle, 1987 J.A. Moore, P.R. Kyle Volcanic geology of Mt. Erebus, Ross Island, Antarctica. Procs NIPR Symposium Antarctic Geosci., 1 (1987), pp. 46-65

Moretti, 2005 R. Moretti Polymerisation, basicity, oxidation state and their role in ionic modelling of silicate melts Annals Geophysics, 48 (4/5) (2005), pp. 583-608

Moretti and Baker, 2008 R. Moretti, D.R. Baker Modeling of the interplay of $\mathrm{fO}_{2}$ and $\mathrm{fS}_{2}$ along the FeS-Silicate Melt equilibrium Chem. Geol., 256 (2008), pp. 286-298

Moretti and Ottonello, 2005 R. Moretti, G. Ottonello Solubility and speciation of sulfur in silicate melts: the Conjugated-Toop-Samis-Flood-Grjotheim (CTSFG) model Geochim. Cosmochim. Acta, 69 (2005), pp. 801-823

Moretti and Papale, 2004 R. Moretti, P. Papale On the oxidation state and volatile behavior in multicomponent gas-melt equilibria Chem. Geol., 213 (2004), pp. 265-280

Moretti et al., 2003 R. Moretti, P. Papale, G. Ottonello A model for the saturation of C-HO-S fluids in silicate melts ,in: C. Oppenheimer, D.M. Pyle, J. Barclay (Eds.), Volcanic Degassing, Geol. Soc. Lond. Spec. Publ., 213 (2003), pp. 81-101 
Murray et al., 2006 Murray, M.H., Kyle, P.R., Aster, R.C., Bartel, B., 2006. Continuous GPS Measurement of Deformation at Erebus Volcano, Antartica, American Geophysical Union, Fall Meeting 2006, abstract \#G53A-0884.

Oppenheimer and Kyle, 2008 C. Oppenheimer, P.R. Kyle Probing the magma plumbing of Erebus volcano, Antarctica, by open-path FTIR spectroscopy of gas emissions J. Volcanol. Geotherm. Res., 177 (2008), pp. 743-754

Oppenheimer et al., 2009 C. Oppenheimer, A. Lomakina, P.R. Kyle, N.G. Kingsbury, M. Boichu Pulsatory magma supply to Erebus lava lake, Antarctica Earth Planet. Sci. Lett., 284 (2009), pp. 392-398

Orlando et al., 2000 A. Orlando, S. Conticelli, P. Armienti, D. Borrini Experimental study on a basanite from the McMurdo Volcanic Group, Antarctica: inference on its mantle source Antarctic Sci., 12 (2000), pp. 105-116

Ottonello et al., 2001 G. Ottonello, R. Moretti, L. Marini, Zuccolini M. Vetuschi Oxidation state of iron in silicate melts: a thermochemical model Chem. Geol., 174 (2001), pp. 157-179

Papale et al., 2006 P. Papale, R. Moretti, D. Barbato The compositional dependence of the saturation surface of $\mathrm{H}_{2} \mathrm{O}+\mathrm{CO}_{2}$ fluids in silicate melts Chem. Geol., 229 (2006), pp. 7895

Quareni et al., 2007 F. Quareni, R. Moretti, M. Piochi, G. Chiodini Modeling of the thermal state of Mt. Vesuvius from $1631 \mathrm{AD}$ to present and the role of $\mathrm{CO}_{2}$ degassing on the volcanic conduit closure after the 1944 AD eruption J. Geophys. Res., 112 (2007) http://dx.doi.org/10.1029/2005JB003841 B03202

Rocchi et al., 2002 S. Rocchi, P. Armienti, M. D'Orazio, S. Tonarini, J.R. Wijbrans, G. Di Vincenzo Cenozoic magmatism in the western Ross Embayment: role of mantle plume versus plate dynamics in the development of the West Antarctic Rift System J. Geophys. Res., 107 (B9) (2002), p. 2195 http://dx.doi.org/10.1029/2001JB000515

Rocchi et al., 2003 S. Rocchi, F. Storti, G. Di Vincenzo, F. Rosetti Intraplate strike-slip tectonics as an alternative to mantle plume activity for the Cenozoic rift magmatism in the Ross Sea region, Antarctica ,in: F. Storti, R.E. Holdsworth, F. Salvini (Eds.), Intraplate Strike-Slip Deformation Belts, Geol. Soc. Lond. Spec. Publ., 210 (2003), pp. 145-158

Rocchi et al., 2005 S. Rocchi, P. Armienti, G. Di Vincenzo No plume, no rift magmatism in the West Antarctic Rift ,in: G.R. Foulger, J.H. Natland, D.C. Presnall, D.L. Anderson (Eds.), Plates, Plumes and Paradigms, Geol. Soc. Am. Spec. Publ., 388 (2005), pp. 435447

Sahama, 1978 T.G. Sahama The Nyiragongo main cone. Annales, Musée Royal de l'Afrique Centrale, Tervuren, Série in-8 Sci. Géol., 8 (1978), p. 88

Santosh and Omori, 2008 M. Santosh, S. Omori CO2 flushing: a plate tectonic perspective Gondwana Research, 13 (2008), pp. 86-102 
Sawyer et al., 2008 G.M. Sawyer, S.A. Carn, V.I. Tsanev, C. Oppenheimer, M. Burton Investigation into magma degassing at Nyiragongo volcano, Democratic Republic of Congo Geochem. Geophys. Geosyst., 9 (2008), p. Q02017 http://dx.doi.org/10.1029/2007GC001829

Schuessler et al., 2008 J.A. Schuessler, R.E. Botcharnikov, H. Behrens, V. Misiti, C. Freda Oxidation state of iron in hydrous phono-tephritic melts Am. Mineral., 93 (2008), pp. 1493-1504

Shinohara et al., 2008 H. Shinohara, A. Aiuppa, G. Giudice, S. Gurrieri, M. Liuzzo Variation of $\mathrm{H}_{2} \mathrm{O} / \mathrm{CO}_{2}$ and $\mathrm{CO}_{2} / \mathrm{SO}_{2}$ ratios of volcanic gases discharged by continuous degassing of Mount Etna volcano, Italy J. Geophys. Res., 113 (2008), p. B09203 http://dx.doi.org/10.1029/2007JB005185

Sims et al., 2008 K.W.W. Sims, J. Blichert-Toft, P.R. Kyle, S. Pichat, P.-J. Gauthier, J. Bluztajn, P. Kelly, L. Ball, G. Layne A Sr, Nd, Hf, and Pb isotope perspective on the genesis and long-term evolution of alkaline magmas from Erebus volcano Antarctica. J. Volcanol. Geotherm. Res., 177 (2008), pp. 606-618

Spilliaert et al., 2006 N. Spilliaert, P. Allard, N. Métrich, A.V. Sobolev Melt inclusion record of the conditions of ascent, degassing, and extrusion of volatile-rich alkali basalt during the powerful 2002 flank eruption of Mount Etna (Italy) J. Geophys. Res., 111 (B4) (2006), p. B04203 http://dx.doi.org/10.1029/2005JB003934

Stuckless and Ericksen, 1976 J.S. Stuckless, R.L. Ericksen Strontium isotopic geochemistry of the volcanic rocks and associated megacrysts and inclusions from Ross Island and vicinity Antarctica. Contrib. Mineral. Petrol., 58 (1976), pp. 111-126

Sweeney et al., 2008 D. Sweeney, P.R. Kyle, C. Oppenheimer Sulfur dioxide emissions and degassing behavior of Erebus volcano Antarctica. J. Volcanol. Geotherm. Res., 177 (2008), pp. 725-733

Trigila and De Benedetti, 1993 R. Trigila, A.A. De Benedetti Petrogenesis of Vesuvius historical lavas constrained by Pearce element ratios analysis and experimental phase equilibria J. Volcanol. Geotherm. Res., 58 (1993), pp. 315-343

Vigouroux et al., 2008 N. Vigouroux, P.J. Wallace, A.J.R. Kent Volatiles in High-K magmas from the Western Trans-Mexican Volcanic Belt: evidence from fluid fluxing and extreme enrichment of the mantle wedge by subduction processes J. Petrol., 49 (2008), pp. $1589-1618$

Wardell et al., 2004 L.J. Wardell, P.R. Kyle, C. Chaffin Carbon dioxide and carbon monoxide emission rates from an alkaline intra-plate volcano: Mt. Erebus Antarctica. J. Volcanol. Geotherm. Res., 131 (2004), pp. 109-121

Werner and Brantley, 2003 C. Werner, S. Brantley $\mathrm{CO}_{2}$ emissions from the Yellowstone volcanic system Geochem. Geophys. Geosyst., 4 (2003), p. 1061 http://dx.doi.org/10.1029/2002GC000473 
Witham et al., 2006 F. Witham, A.W. Woods, C. Gladstone An analogue experimental model of depth fluctuations in lava lakes Bull. Volcanol., 69 (2006), pp. 51-56

Wörner, 1999 G. Wörner Lithospheric dynamics and mantle sources of alkaline magmatism of the Cenozoic West Antarctic Rift System Global Planet. Change, 23 (1999), pp. 61-77

Wysoczanski et al., 1995 R.J. Wysoczanski, J.A. Gamble, P.R. Kyle, M.F. Thirlwall The petrology of lower crustal xenoliths from the Executive Committee Range, Marie Byrd Land Volcanic Province, West Antarctica Lithos, 36 (1995), pp. 185-201

Zipfel and Wörner, 1992 J. Zipfel, G. Wörner Four- and five-phase peridotites from a continental rift system: evidence for upper mantle uplift and cooling at the Ross Sea margin (Antarctica) Contrib. Mineral. Petrol., 111 (1992), pp. 24-36

Zreda-Gostynska et al., 1997 G. Zreda-Gostynska, P.R. Kyle, D. Finnegan, K.M. Prestbo Volcanic gas emissions from Mount Erebus and their impact on the Antarctic environment J. Geophys. Res., 102 (B7) (1997), pp. 15039-15055 
Table 1. $\mathrm{CO}_{2} / \mathrm{CO}$ and $\mathrm{CO}_{2} / \mathrm{H}_{2} \mathrm{O}$ ratios of gases released by Strombolian explosions at Erebus volcano.

\begin{tabular}{|c|c|c|c|c|c|}
\hline $\begin{array}{l}\text { Explosion } \\
\text { time (UTC) }\end{array}$ & 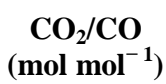 & $\begin{array}{c}\mathrm{CO}_{2} / \mathrm{H}_{2} \mathrm{O} \\
\left(\mathrm{mol} \mathrm{mol}^{-1}\right)\end{array}$ & $\begin{array}{l}\mathrm{CO}_{2} / \mathrm{H}_{2} \mathrm{O} \\
\left(\mathrm{kg} \mathrm{kg}^{-1}\right)\end{array}$ & $\operatorname{Size}^{-}$ & Remarks \\
\hline $\begin{array}{l}12 / 12 / 2005 \\
01: 37\end{array}$ & 45 & 0.61 & 1.5 & 10 & $8 \mathrm{~s}$ time resolution (i.e., 8 co-added spectra). No video. \\
\hline $\begin{array}{l}12 / 12 / 2005 \\
02: 21\end{array}$ & 54 & 1.1 & 2.7 & 9 & $8 \mathrm{~s}$ time resolution (i.e., 8 co-added spectra). No video. \\
\hline $\begin{array}{l}13 / 12 / 2005 \\
16: 57\end{array}$ & 58 & 1.8 & 4.4 & 10 & $\begin{array}{l}\text { Large explosion; very clear in crater; lake surface } \\
\text { distends a few s before explosion. Some ash in cloud; } \\
\text { lake partially eviscerated; some steam clouds from } \\
\text { bombs in snow. }\end{array}$ \\
\hline $\begin{array}{l}13 / 12 / 2005 \\
23: 19\end{array}$ & 87 & 0.94 & 2.3 & 7 & $\begin{array}{l}\text { Very clear in crater; much lava ejected from lake; ash } \\
\text { cloud produced. }\end{array}$ \\
\hline $\begin{array}{l}14 / 12 / 2005 \\
11: 48\end{array}$ & 58 & 0.65 & 1.6 & 10 & $\begin{array}{l}\text { Partially hazy in the crater; much lava expelled; ashy } \\
\text { clouds produced. }\end{array}$ \\
\hline $\begin{array}{l}15 / 12 / 2005 \\
03: 15\end{array}$ & 66 & 1.7 & 4.1 & 9 & Very clear in crater; much lava expelled from lake. \\
\hline $\begin{array}{l}15 / 12 / 2005 \\
09: 19\end{array}$ & 63 & 3.4 & 8.3 & 8 & $\begin{array}{l}\text { Smaller bombs than other large explosions; somewhat } \\
\text { hazy in crater. }\end{array}$ \\
\hline $\begin{array}{l}16 / 12 / 2005 \\
05: 51\end{array}$ & 97 & 2.6 & 6.3 & 4 & No video. \\
\hline $\begin{array}{l}19 / 12 / 2005 \\
06: 30\end{array}$ & 65 & 1.8 & 4.3 & 4 & Remarkable bubble burst; very clear in crater. \\
\hline $\begin{array}{l}19 / 12 / 2005 \\
09: 39\end{array}$ & 69 & 1.5 & 3.7 & 10 & Very clear in crater; ashy explosion. \\
\hline $\begin{array}{l}21 / 12 / 2005 \\
09: 38\end{array}$ & 130 & 21 & 5.1 & 10 & $\begin{array}{l}\text { Very clear; lake distends before explosion; much lava } \\
\text { expelled from lake; steam from fizzing bombs passes } \\
\text { across field of view. High } \mathrm{CO}_{2} / \mathrm{CO} \text { constrained by only } \\
\text { one data pair as plume rapidly dominated by passive } \\
\text { emission. }\end{array}$ \\
\hline $\begin{array}{l}25 / 12 / 2005 \\
07: 53\end{array}$ & 93 & 2.4 & 5.7 & 10 & No video. \\
\hline $\begin{array}{l}27 / 12 / 2005 \\
05: 21\end{array}$ & 110 & 4.0 & 9.8 & NA & Fumy in crater; much lava expelled from lake. \\
\hline $\begin{array}{l}29 / 12 / 2005 \\
01: 23\end{array}$ & 72 & 2.3 & 5.7 & 10 & Very clear before explosion, then fumy (ashy?). \\
\hline $\begin{array}{l}31 / 12 / 2005 \\
06: 12\end{array}$ & 64 & 1.5 & 3.6 & NA & $\begin{array}{l}\text { Very clear in crater; large explosion; much spatter } \\
\text { towards Rays. }\end{array}$ \\
\hline $\begin{array}{l}31 / 12 / 2005 \\
06: 36\end{array}$ & 57 & 3.0 & 7.2 & NA & $\begin{array}{l}\text { Very clear in crater; large explosion evacuating part of } \\
\text { the lake; lake distends before explosion. }\end{array}$ \\
\hline $\begin{array}{l}\text { 01/01/2006 } \\
03: 22\end{array}$ & 56 & 1.6 & 3.9 & NA & No video \\
\hline
\end{tabular}




\section{a}

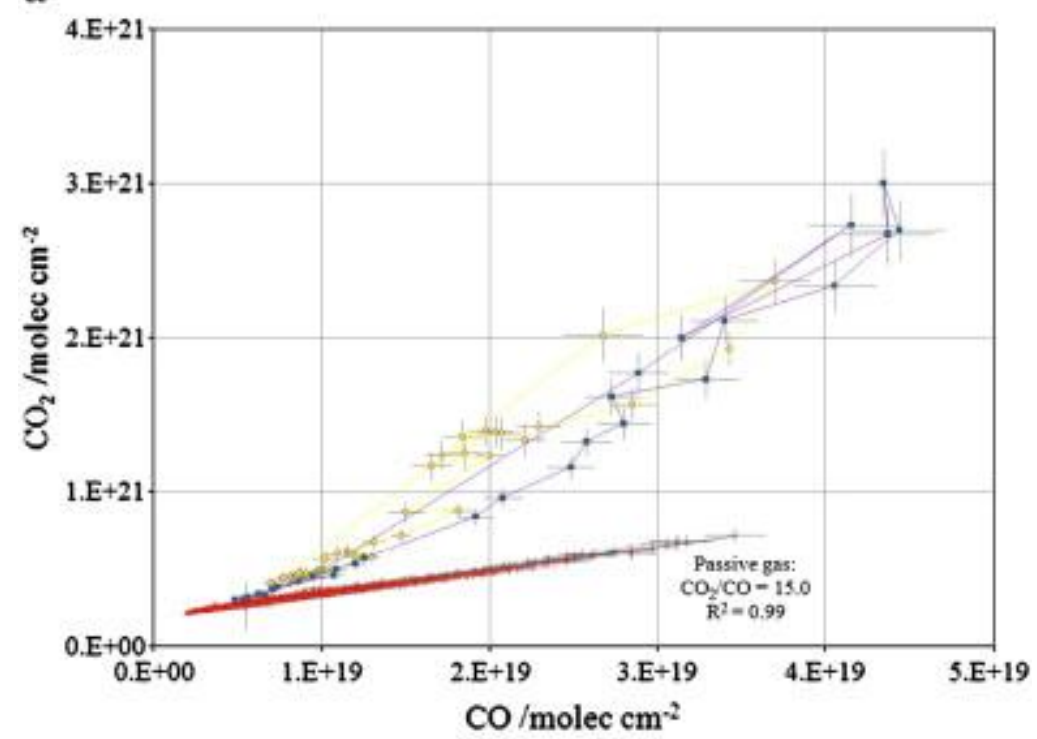

b

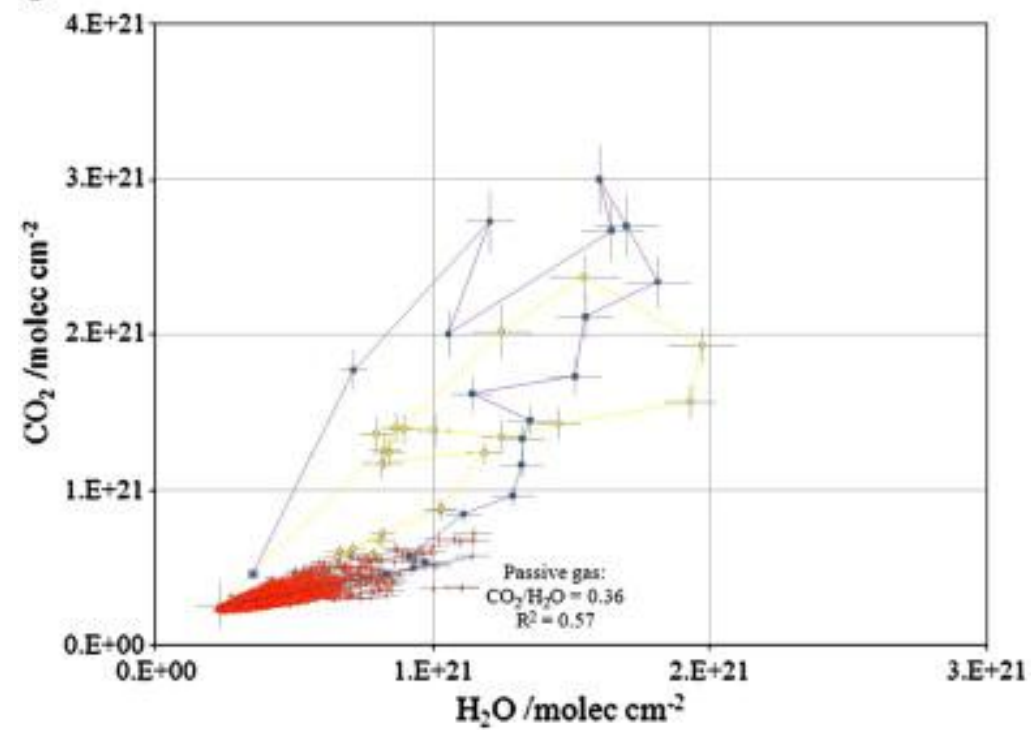

Fig. 1. Spectroscopic measurements of (a) $\mathrm{CO}_{2}$ versus $\mathrm{CO}$, and (b) $\mathrm{CO}_{2}$ versus $\mathrm{H}_{2} \mathrm{O}$ column amounts for passive (red triangles) and explosive emissions on 15 December 2005. There were two large explosions on this day at 03:15 (yellow circles) and 09:19 (purple squares) UT. Note the fairly consistent $\mathrm{CO}_{2} / \mathrm{CO}$ ratio for both explosions $\left(\sim 65 \mathrm{~mol} \mathrm{~mol}^{-1}\right)$. The time step between spectral acquisitions was $\sim 1 \mathrm{~s}$ and the tie lines connecting individual explosive gas retrievals show the second-by-second time evolution of the plume. It is more difficult to estimate the $\mathrm{CO}_{2} / \mathrm{H}_{2} \mathrm{O}$ ratio of the explosive gas but it is, in nearly all explosions, significantly higher than that for passive gas emission. We use the first few measurements immediately after each explosion to characterise the $\mathrm{CO}_{2} / \mathrm{H}_{2} \mathrm{O}$ ratio. The reason for the scatter in retrieved $\mathrm{CO}_{2} / \mathrm{H}_{2} \mathrm{O}$ ratios immediately after explosions is unclear but may have something to do with vigorous water degassing as the lake rapidly recharges (larger explosions expel a substantial volume of magma from the lava lake), and consequent mixing of explosive and passive gases. There is a hint that this is the case in the 03:15 explosion seen in (b, yellow circles) where the initial trajectory of the retrievals reveals high $\mathrm{CO}_{2} / \mathrm{H}_{2} \mathrm{O}$, then heads towards a more water-rich composition, but then back briefly to the same high $\mathrm{CO}_{2} / \mathrm{H}_{2} \mathrm{O}$ values $\sim 6 \mathrm{~s}$ after the explosion. The same effect is apparent in the $\mathrm{CO}_{2} / \mathrm{CO}$ trend for this explosion in (a). 
Table 2. Average major oxide and volatile contents of crystal-hosted melt inclusions in samples from the Erebus Lineage.

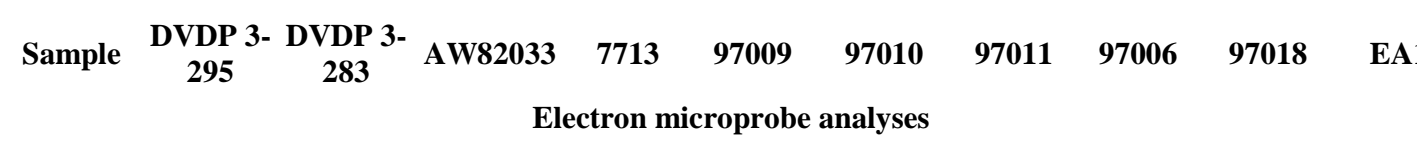

\begin{tabular}{|c|c|c|c|c|c|c|c|c|c|c|}
\hline & $n=10$ & $n=4$ & $n=11$ & $n=8$ & $n=10$ & $n=6$ & $n=6$ & $n=4$ & $n=7$ & $n=10$ \\
\hline $\begin{array}{l}\mathrm{SiO}_{2} \\
\text { (wt.\%) }\end{array}$ & $\begin{array}{l}41.03 \\
(1.10)\end{array}$ & $\begin{array}{l}41.85 \\
(1.34)\end{array}$ & $\begin{array}{l}44.75 \\
(1.76)\end{array}$ & $\begin{array}{l}47.72 \\
(0.39)\end{array}$ & $\begin{array}{l}51.11 \\
(1.61)\end{array}$ & $\begin{array}{l}53.56 \\
(0.62)\end{array}$ & $\begin{array}{l}53.77 \\
(1.15)\end{array}$ & $\begin{array}{l}54.46 \\
(0.54)\end{array}$ & $\begin{array}{l}55.64 \\
(0.88)\end{array}$ & $\begin{array}{l}54.83 \\
(0.60)\end{array}$ \\
\hline $\begin{array}{l}\mathrm{TiO}_{2} \\
\text { (wt.\%) }\end{array}$ & $\begin{array}{l}4.14 \\
(0.15)\end{array}$ & $\begin{array}{l}4.17 \\
(0.18)\end{array}$ & $3.56(0.55)$ & $\begin{array}{l}2.70 \\
(0.17)\end{array}$ & $\begin{array}{l}1.82 \\
(0.17)\end{array}$ & $\begin{array}{l}1.87 \\
(0.17)\end{array}$ & $\begin{array}{l}1.34 \\
(0.14)\end{array}$ & $\begin{array}{l}1.35 \\
(0.07)\end{array}$ & $\begin{array}{l}0.96 \\
(0.09)\end{array}$ & $\begin{array}{l}0.95 \\
(0.04)\end{array}$ \\
\hline $\begin{array}{l}\mathrm{Al}_{2} \mathrm{O}_{3} \\
\text { (wt.\%) }\end{array}$ & $\begin{array}{l}14.56 \\
(0.57)\end{array}$ & $\begin{array}{l}14.10 \\
(0.48)\end{array}$ & $\begin{array}{l}17.36 \\
(0.85)\end{array}$ & $\begin{array}{l}17.81 \\
(0.31)\end{array}$ & $\begin{array}{l}19.28 \\
(0.47)\end{array}$ & $\begin{array}{l}19.63 \\
(0.54)\end{array}$ & $\begin{array}{l}20.07 \\
(0.32)\end{array}$ & $\begin{array}{l}19.68 \\
(0.11)\end{array}$ & $\begin{array}{l}20.16 \\
(0.49)\end{array}$ & $\begin{array}{l}19.79 \\
(0.28)\end{array}$ \\
\hline $\begin{array}{l}\mathrm{FeO}_{\mathrm{T}} \\
\text { (wt.\%) }\end{array}$ & $\begin{array}{l}10.26 \\
(0.96)\end{array}$ & $\begin{array}{l}10.33 \\
(1.58)\end{array}$ & $\begin{array}{l}10.83 \\
(1.02)\end{array}$ & $\begin{array}{l}10.43 \\
(0.28)\end{array}$ & $\begin{array}{l}7.17 \\
(0.40)\end{array}$ & $\begin{array}{l}6.71 \\
(0.49)\end{array}$ & $\begin{array}{l}5.43 \\
(0.21)\end{array}$ & $\begin{array}{l}5.78 \\
(0.16)\end{array}$ & $\begin{array}{l}5.38 \\
(0.22)\end{array}$ & $\begin{array}{l}4.98 \\
(0.10)\end{array}$ \\
\hline $\begin{array}{l}\mathrm{MnO} \\
\text { (wt.\%) }\end{array}$ & $\begin{array}{l}0.16 \\
(0.02)\end{array}$ & $\begin{array}{l}0.19 \\
(0.01)\end{array}$ & $0.23(0.06)$ & $\begin{array}{l}0.25 \\
(0.03)\end{array}$ & $\begin{array}{l}0.20 \\
(0.02)\end{array}$ & & & $\begin{array}{l}0.21 \\
(0.01)\end{array}$ & $\begin{array}{l}0.27 \\
(0.05)\end{array}$ & $\begin{array}{l}0.25 \\
(0.03)\end{array}$ \\
\hline $\begin{array}{l}\mathrm{MgO} \\
\text { (wt.\%) }\end{array}$ & $\begin{array}{l}5.85 \\
(0.24)\end{array}$ & $\begin{array}{l}5.85 \\
(0.43)\end{array}$ & $3.59(0.45)$ & $\begin{array}{l}2.31 \\
(0.29)\end{array}$ & & $\begin{array}{l}1.21 \\
(0.11)\end{array}$ & & & $\begin{array}{l}0.84 \\
(0.03)\end{array}$ & \\
\hline $\begin{array}{l}\mathrm{CaO} \\
(\mathrm{wt} . \%)\end{array}$ & $\begin{array}{l}12.85 \\
(0.98)\end{array}$ & $\begin{array}{l}13.74 \\
(0.39)\end{array}$ & $9.43(1.69)$ & $\begin{array}{l}6.71 \\
(0.32)\end{array}$ & & & & & & \\
\hline $\begin{array}{l}\mathrm{Na}_{2} \mathrm{O} \\
\text { (wt.\%) }\end{array}$ & $\begin{array}{l}3.69 \\
(0.31)\end{array}$ & $\begin{array}{l}3.53 \\
(0.46)\end{array}$ & $5.03(0.51)$ & $\begin{array}{l}6.21 \\
(0.63)\end{array}$ & $\begin{array}{l}7.65 \\
(0.44)\end{array}$ & & & & $\begin{array}{l}8.98 \\
(0.27)\end{array}$ & $\begin{array}{l}8.82 \\
(0.27)\end{array}$ \\
\hline $\begin{array}{l}\mathrm{K}_{2} \mathrm{O} \\
\text { (wt.\%) }\end{array}$ & $\begin{array}{l}1.63 \\
(0.13)\end{array}$ & $\begin{array}{l}1.54 \\
(0.14)\end{array}$ & $2.43(0.78)$ & $\begin{array}{l}3.49 \\
(0.07)\end{array}$ & & & & & & $\begin{array}{l}6.29 \\
(0.27)\end{array}$ \\
\hline $\begin{array}{l}\mathrm{P}_{2} \mathrm{O}_{5} \\
\text { (wt.\%) }\end{array}$ & $\begin{array}{l}0.92 \\
(0.07)\end{array}$ & $\begin{array}{l}0.78 \\
(0.09)\end{array}$ & $1.31(0.28)$ & $\begin{array}{l}1.30 \\
(0.15)\end{array}$ & & & & & & \\
\hline$(\mathrm{ppm})$ & $\begin{array}{l}1572 \\
(325)\end{array}$ & $\begin{array}{l}1978 \\
(228)\end{array}$ & 2133 (713) & $\begin{array}{l}2774 \\
(480)\end{array}$ & & $\begin{array}{l}2406 \\
(672)\end{array}$ & & $\begin{array}{l}1973 \\
(725)\end{array}$ & $\begin{array}{l}2254 \\
(513)\end{array}$ & $\begin{array}{l}2652 \\
(347)\end{array}$ \\
\hline $\mathrm{S}(\mathrm{ppm})$ & $\begin{array}{l}2166 \\
(228)\end{array}$ & $\begin{array}{l}2036 \\
(114)\end{array}$ & $1330(244)$ & $\begin{array}{l}1109 \\
(247)\end{array}$ & $\begin{array}{l}671 \\
(131)\end{array}$ & $616(157)$ & $\begin{array}{l}628 \\
(145)\end{array}$ & $\begin{array}{l}658 \\
(185)\end{array}$ & $367(131)$ & 375 \\
\hline $\mathrm{Cl}(\mathrm{ppm})$ & $875(175)$ & $740(122)$ & $784(182)$ & $\begin{array}{l}1038 \\
(170)\end{array}$ & $\begin{array}{l}2172 \\
(2053)\end{array}$ & $\begin{array}{l}1223 \\
(154)\end{array}$ & $\begin{array}{l}1352 \\
(144)\end{array}$ & $\begin{array}{l}1325 \\
(135)\end{array}$ & $\begin{array}{l}1457 \\
(163)\end{array}$ & $\begin{array}{l}1502 \\
(171)\end{array}$ \\
\hline $\begin{array}{l}\text { Total } \\
\text { (wt.\%) }\end{array}$ & $\begin{array}{l}95.55 \\
(1.82)\end{array}$ & $\begin{array}{l}96.56 \\
(1.04)\end{array}$ & $\begin{array}{l}98.94 \\
(1.65)\end{array}$ & $\begin{array}{l}99.42 \\
(0.94)\end{array}$ & $\begin{array}{l}98.39 \\
(2.55)\end{array}$ & $\begin{array}{l}101.14 \\
(0.57)\end{array}$ & $\begin{array}{l}99.51 \\
(1.61)\end{array}$ & $\begin{array}{l}99.58 \\
(0.55)\end{array}$ & $\begin{array}{l}100.50 \\
(1.55)\end{array}$ & $\begin{array}{l}99.27 \\
(1.11)\end{array}$ \\
\hline \multicolumn{11}{|c|}{ Fourier Transform Infrared analyses } \\
\hline $\begin{array}{l}\mathrm{CO}_{2} \\
(\mathrm{ppm})\end{array}$ & $\begin{array}{l}5520 \\
(973)\end{array}$ & $\begin{array}{l}5648 \\
(815)\end{array}$ & $825(623)$ & $\begin{array}{l}448 \\
(149)\end{array}$ & $\begin{array}{l}2421 \\
(707)\end{array}$ & 877 (507) & $\begin{array}{l}1118 \\
(587)\end{array}$ & $\begin{array}{l}1166 \\
(367)\end{array}$ & 650 (139) & $\begin{array}{l}690 \\
(125)\end{array}$ \\
\hline $\begin{array}{l}\mathrm{H}_{2} \mathrm{O} \\
\text { (wt.\%) }\end{array}$ & $\begin{array}{l}1.50 \\
(0.19)\end{array}$ & $\begin{array}{l}1.41 \\
(0.24)\end{array}$ & $0.16(0.07)$ & $\begin{array}{l}0.11 \\
(0.02)\end{array}$ & $\begin{array}{l}0.53 \\
(0.07)\end{array}$ & $\begin{array}{l}0.12 \\
(0.01)\end{array}$ & $\begin{array}{l}0.10 \\
(0.02)\end{array}$ & $\begin{array}{l}0.08 \\
(0.01)\end{array}$ & $\begin{array}{l}0.12 \\
(0.05)\end{array}$ & $\begin{array}{l}0.17 \\
(0.02)\end{array}$ \\
\hline
\end{tabular}

$n$ - number of analyses. All inclusions analysed by electron probe were analysed by FTIR spectroscopy.Note: values in parentheses indicate the standard deviation of the mean. 
a

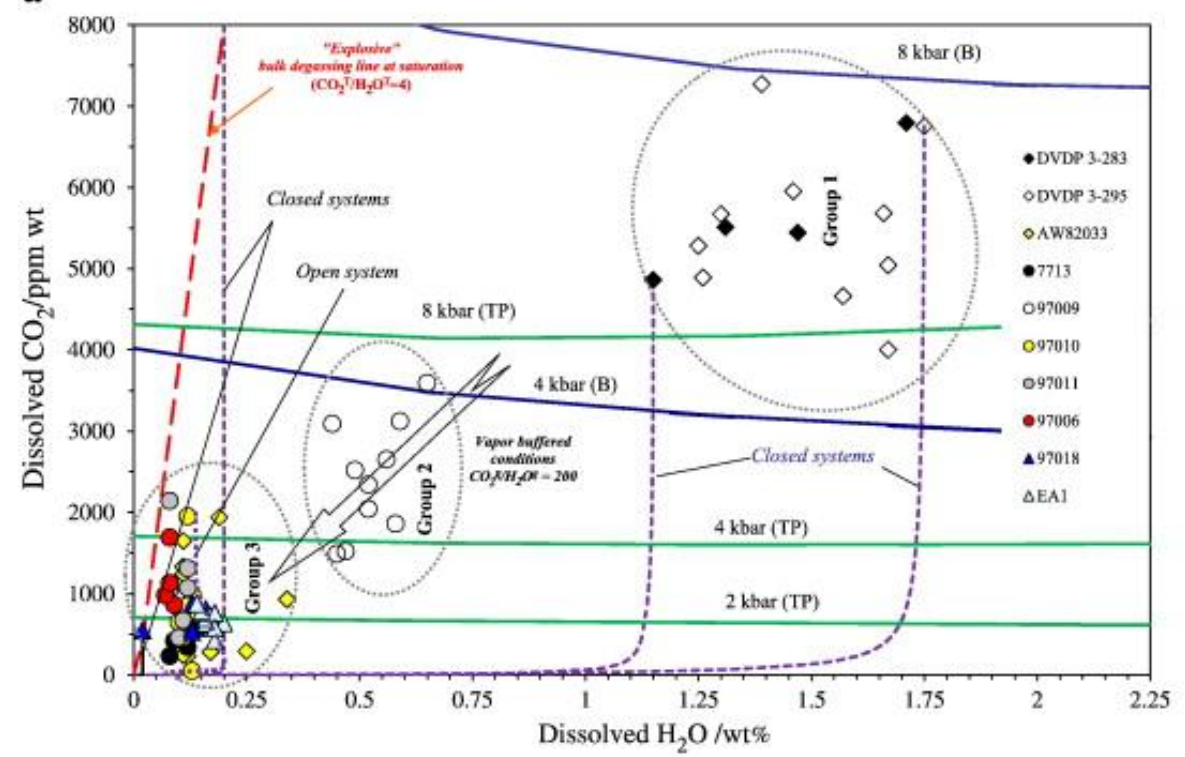

b

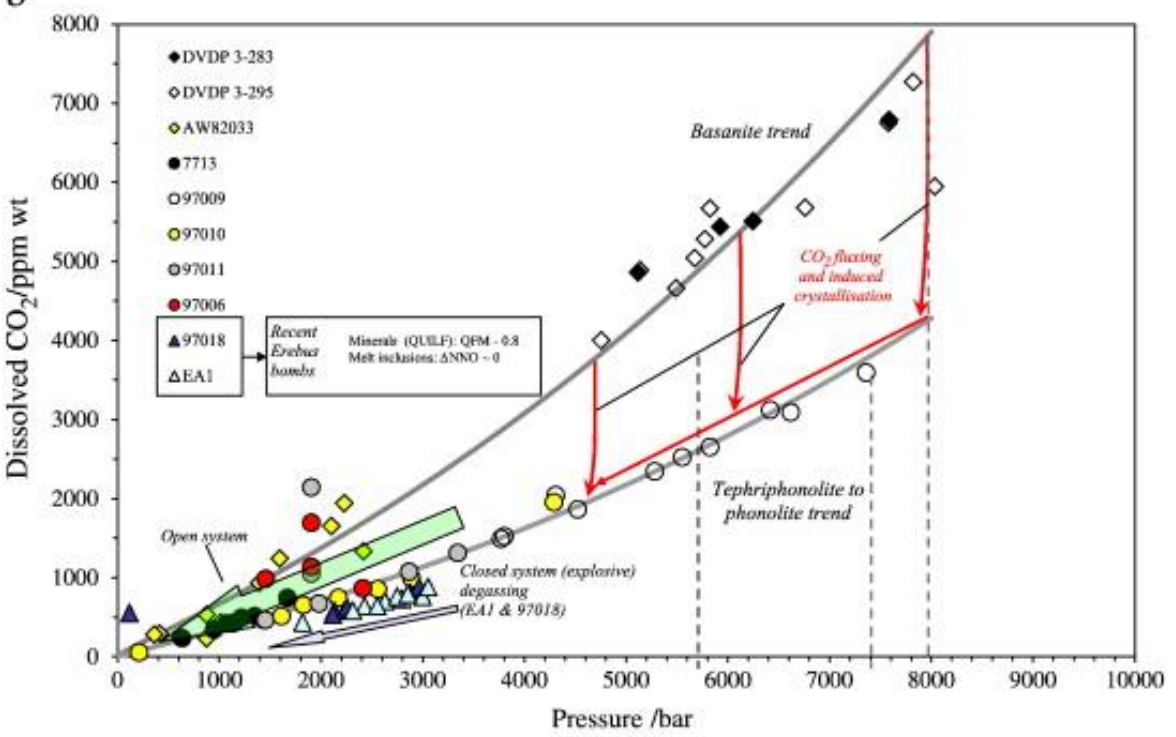

c

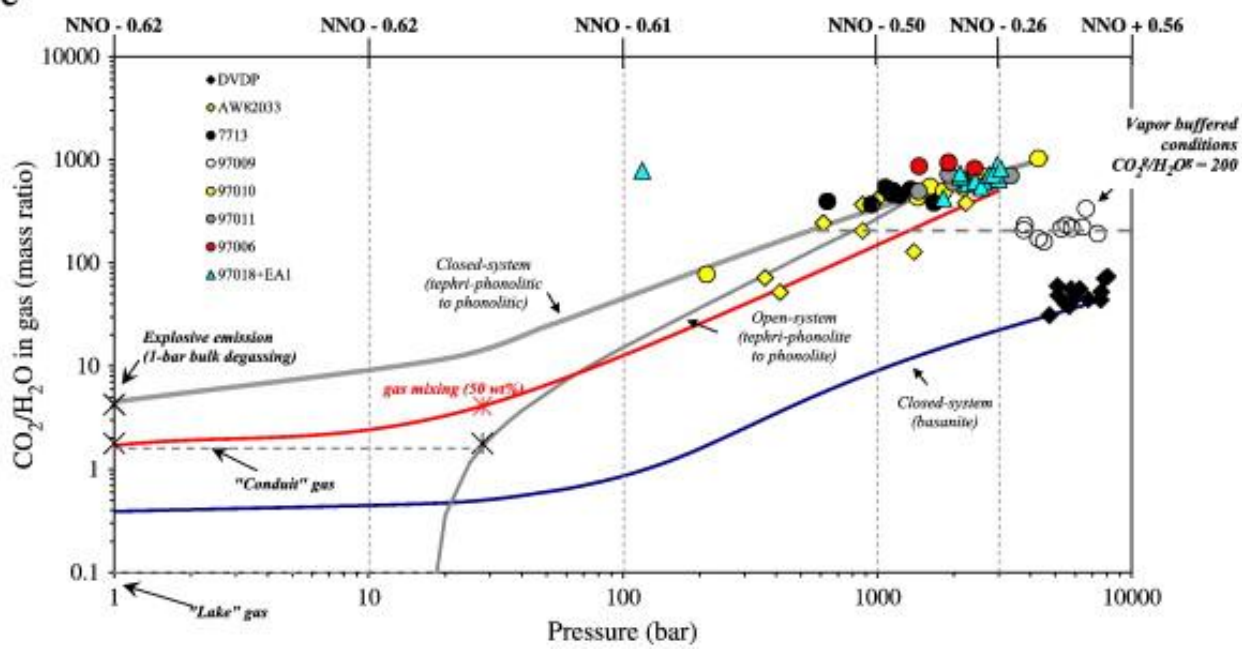

Fig. 2. (a) This diagram reveals the general picture of degassing from basanite to tephriphonolite beneath Erebus volcano, and degassing paths in the range of 0-2.25 wt.\% water. Dotted regions 
denote Groups 1 to 3 (see text). ' $\mathrm{B}$ ' and 'TP' indicate basanite and tephriphonolite, respectively. As discussed in the text, the only way to produce dehydration is via fluxing of $\mathrm{CO}_{2}$-dominated fluids. The arrow shows vapour buffered conditions with almost pure $\mathrm{CO}_{2}$ rising from the mantle, and connecting the deep basanitic 'Group 1' to the more differentiated 'Group 3' melt inclusions, via 'Group 2' tephriphonolites. Low- $\mathrm{H}_{2} \mathrm{O}$-bearing melt inclusion data are bounded by the explosive bulk degassing line, i.e., the bubbles responsible for Strombolian eruptions may be represented by a limiting condition at low pressure and low $\mathrm{H}_{2} \mathrm{O}$ by constraining total volatile contents from the observed gas $\mathrm{H}_{2} \mathrm{O} / \mathrm{CO}_{2}$ ratio. (b) Compositional effect on $\mathrm{CO}_{2}$ saturation with pressure. Note discrimination of trends - one connects DVDP basanites to the AW82033 series. The tephriphonolite (97009) connects with phonolites including the two Erebus bombs. $\mathrm{CO}_{2}$ fluxing and dehydration raise the solidus inducing crystallisation that results in evolution of basanite to tephriphonolite (note that the tephriphonolite and DVDP basanite both reach depths corresponding to $8 \mathrm{kbar}$ ). Note also that isobaric $\mathrm{CO}_{2}$ fluxing (red arrows) does not increase dissolved $\mathrm{CO}_{2}$ because of changing solubility, which is much greater for basanite. (c) Gas phase ratios computed for the plumbing system, observed compositions for explosive and passive degassing through the lava lake, and possible degassing paths. Simple degassing of the source region cannot produce the surface gas composition (closed-system degassing of the basanite source). The "conduit gas" can be produced by opensystem degassing with a final separation at $~ 30$ bar. The closed-path shows step-by-step reequilibration of gas with liquid. Note the divergence between the closed-and open-path trends at low pressure. Explosive degassing can be interpreted as resulting from 1-bar bulk degassing of 'fluxed' phonolite blobs rising under closed-system conditions (two-phase, melt-gas ascent), or as the shallow mixing (heavy red line) between nearly $\mathrm{CO}_{2}$-pure deep gas with the conduit gas (in equal proportions by mass), and taking place in the region where conduit gas is generated ( $P \sim 30$ bar). 


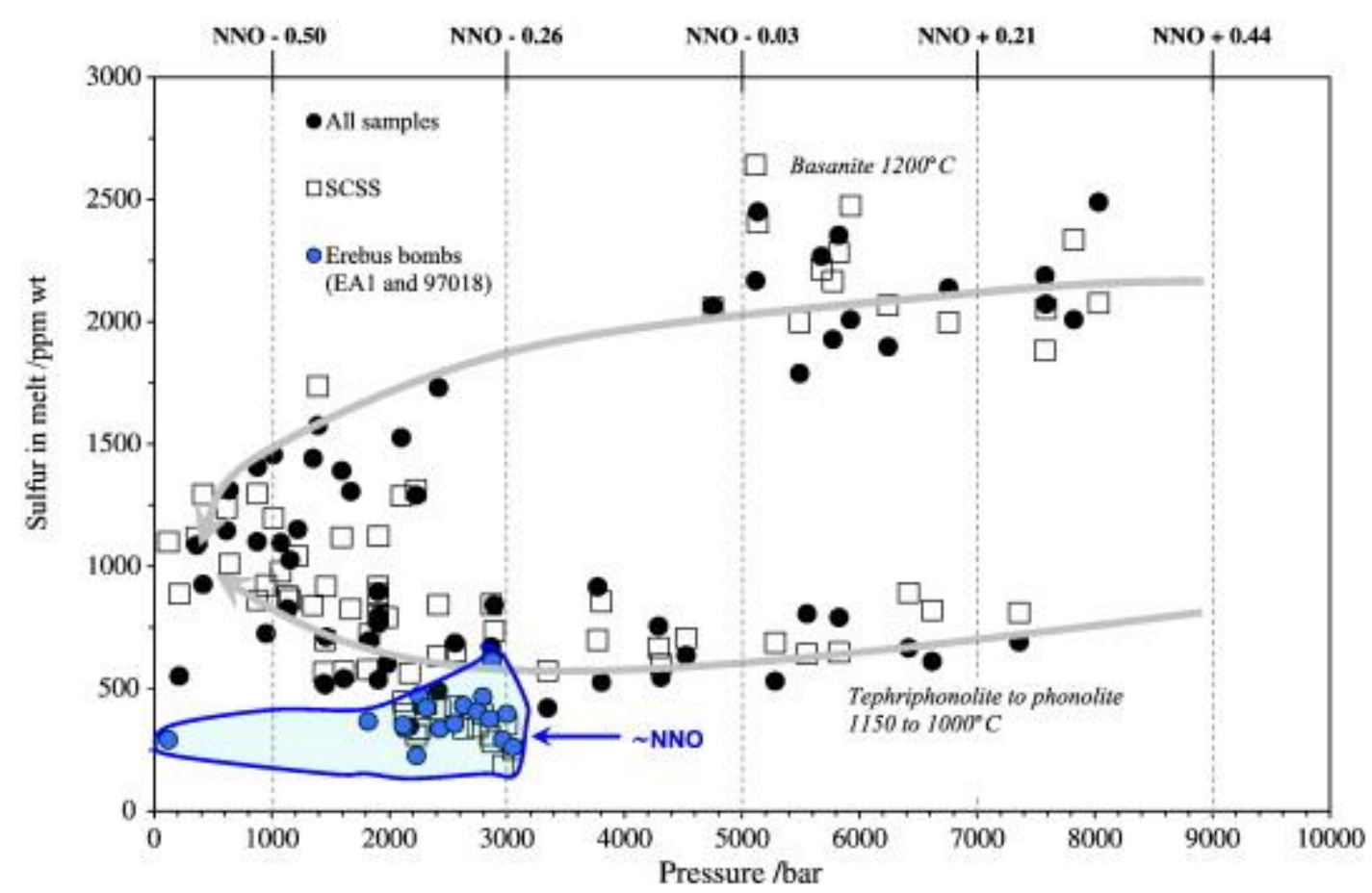

Fig. 3. Sulphur content at sulphide saturation (SCSS) from the model of Moretti and Baker (2008) and based on the occurrence of sulphides throughout the Erebus Lineage. Symbols differ from those used in earlier figures to emphasise the difference between 'shallow' ( $P<3 \mathrm{kbar}$ ) and more oxidised melt inclusions from modern Erebus bombs and the more reduced inclusions from other samples.

Corresponding pairs of measured and computed values fall on the same (vertical) isobar. Plot shows redox conditions required to match SCSS, and identifies a linear $\mathrm{fO}_{2}$ relationship with pressure (log $f \mathrm{O}_{2}=0.000118 P[$ bar $\left.]-0.6176\right)$. The calculation defines $\mathrm{fO}_{2}$ and is based on inputs of $P$, melt composition, $\mathrm{CO}_{2}$ and $\mathrm{H}_{2} \mathrm{O}$. Along the open-system trend, $\mathrm{fO}_{2}$ decreases from NNO to QFM (for the closed-system trend, $\mathrm{fO}_{2}$ stays at $\mathrm{NNO}$ ). Decreasing pressure changes the stability of minerals such as pyrrhotite, and crystallisation of Fe-bearing species, including pyroxene, causes $\mathrm{fO}_{2}$ to decrease - it is thus a secondary result of decreased pressure. Remarkably, the phonolitic melt inclusions in Erebus bombs (blue circles in the shaded blue field) in the lower left-hand region of the plot record $\mathrm{fO}_{2} \sim \mathrm{NNO}$, whereas the lava lake from which the bombs are sourced indicates $\mathrm{fO}_{2}$ well below QFM (Kelly et al., 2008) 


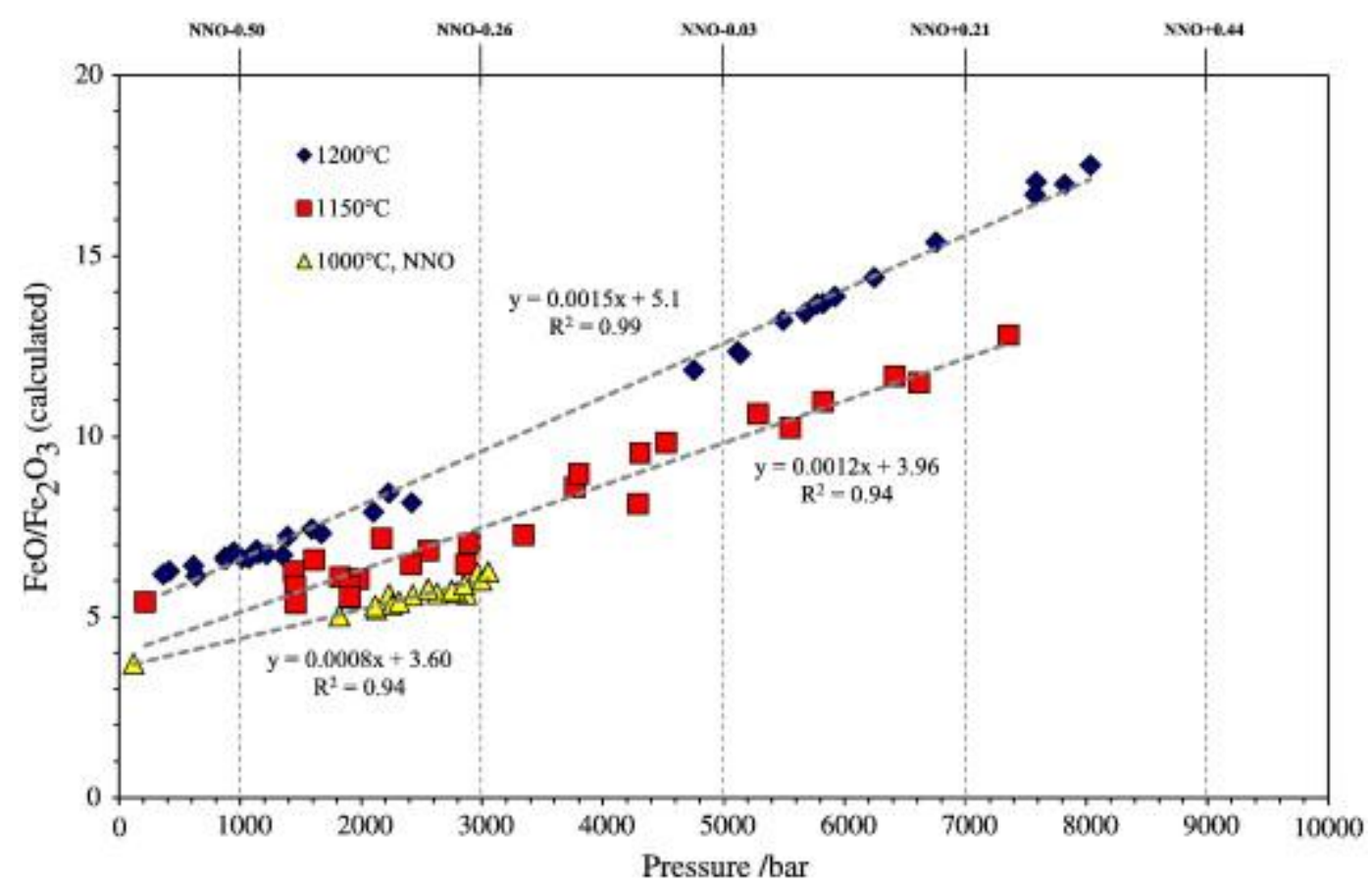

Fig. 4. $\mathrm{FeO} / \mathrm{Fe}_{2} \mathrm{O}_{3}$ ratio calculated from SCSS-derived $f \mathrm{O}_{2}$ values, as in [Ottonello et al., 2001] and [Moretti, 2005]. Compositional systems are divided into three groups according to temperature. Note increasing $\mathrm{FeO} / \mathrm{Fe}_{2} \mathrm{O}_{3}$ with increasing $P$, which seems contradictory in light of the linear decrease of $\log \mathrm{fO}_{2}$ with pressure (see above), making the system more reducing as depth decreases. This is because of the changing composition and the effect of pressure on reactions involving iron species (Moretti and Papale, 2004) and reflects the continuous precipitation of olivine, clinopyroxene, and oxides, which extract Fe(II) from the melt phase. 


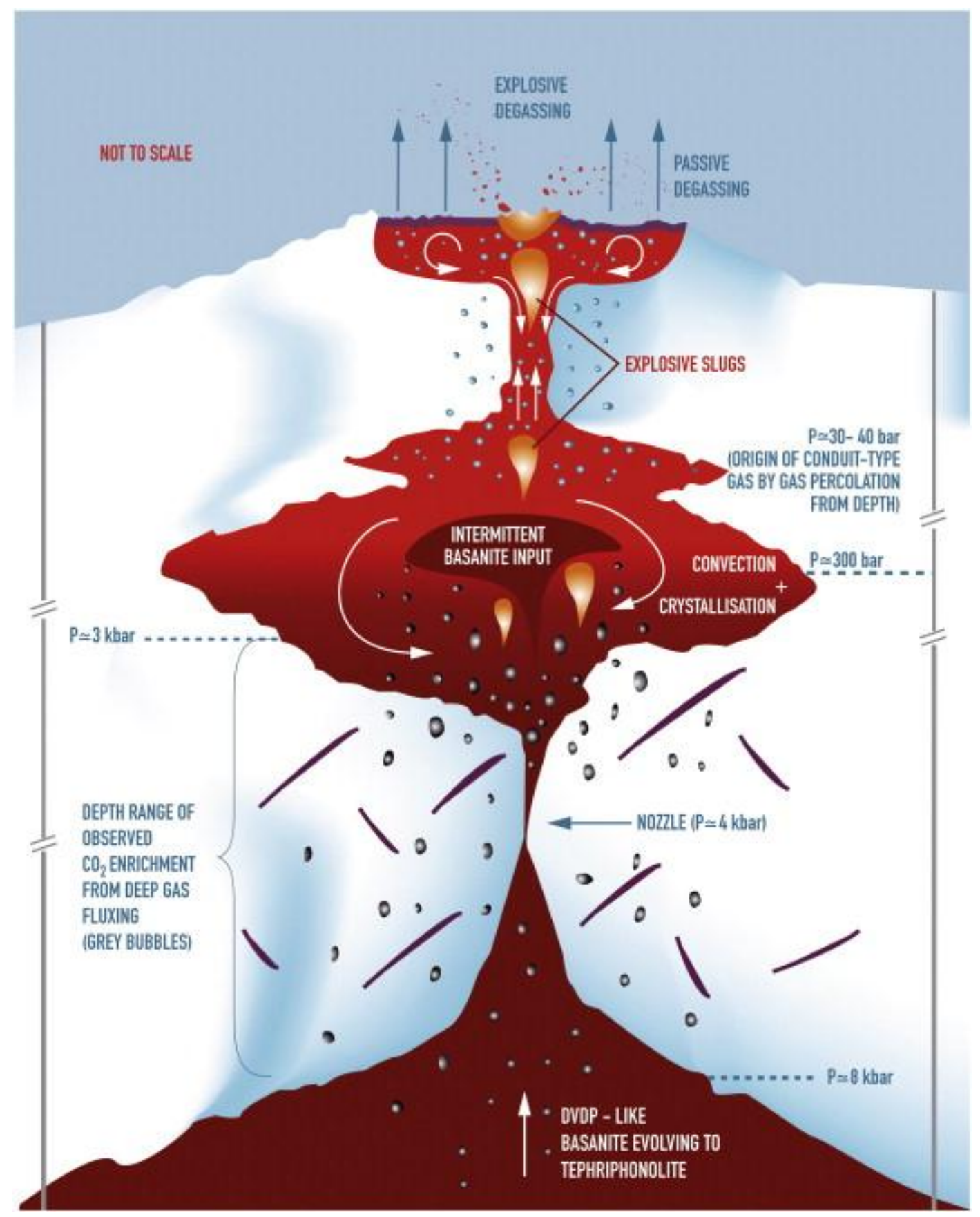

Fig. 5. Conceptual model of the Erebus plumbing system, including the active volcano and neighbouring centres on Ross Island. Deep roots are located just below the crust-mantle transition, or even deeper as suggested by the occurrence of tephriphonolites at similar depths, and likely differentiated by fluxing. The 'nozzle' between the DVDP-like basanite and the overlying reservoir implies predominant gas transfer but with occasional injection of basanite, e.g., represented by sample AW82033, into a large magma chamber. Convection and crystallisation are required to explain the degassing patterns. Some are responsible for the tephriphonolite-to-phonolite evolution, which is associated with open-system degassing that generates the "conduit gas". The arrival of deep, oxidised gas slugs fuels sporadic Strombolian explosions through the lava lake. 